\title{
1. The principles of market and organization in interfirm relationships in the Japanese steel industry
}

Not only after World War II, but also before the war, steel was used very widely and was essential to many industries as a fundamental material; this meant that the steel industry supported a wide range of industries in Japan. In that sense, the steel industry is representative of materials industries. Therefore, in this chapter, I analyze the history of Japan's steel industry, highlighting the interfirm relationship. Indeed, even though there are plenty of splendid studies on the Japanese steel industry before World War II, ${ }^{1}$ they do not focus on interfirm relationships.

Compared with advanced West European countries and the US, Japan was a latecomer to the modern steel industry. That is, Japan started its steel industry in earnest from the early twentieth century although old iron works had already existed in the nineteenth century. However, as will be demonstrated later, Japan had attained self-sufficiency in steel in the 1930s; furthermore, the Japanese steel industry had boasted international competitiveness in the 1960s. For that reason, this chapter covers the period from before the war up to the high economic growth period of postwar. ${ }^{2}$

Based on the viewpoint of the analysis that was emphasized in the introduction, this chapter focuses on how market and organizational principles have intertwined. Section 1.1 depicts how a market principle and an organizational principle intertwined in the steel industry of prewar Japan. Next, section 1.2 takes up interfirm relationships in the Japanese steel industry during the high economic growth period. Finally, I compare the prewar characteristics of steel transactions with the postwar characteristics. 


\subsection{THE PRINCIPLES OF MARKET AND ORGANIZATION IN THE PREWAR PERIOD}

\subsubsection{Market Conditions}

Market conditions, namely the balance of supply and demand, have a great influence on the transaction as an environment. Therefore, before the historical analysis of the interfirm relationship in the steel industry, let me start with a discussion about market conditions in this period.

\subsubsection{In World War I}

In Japan, it was not until World War I that the demand for steel increased in earnest. By the outbreak of the First World War, the demand for steel had exploded. In Western countries, the war brought about the imbalance between military and civil demand. It increased trade and also created the "marine transportation boom" and a shortage of ships, that is, it increased the demand for machines. Accordingly, these industries were booming and created an explosive demand for steel. Japan was no exception. For example, the demand for steel increased from 650000 tons in 1914 to 1122000 tons in 1918 , an increase of approximately 1.7 times. ${ }^{3}$

In response to this explosion in demand, it is clear that Japanese steel companies actively constructed and expanded their rolling equipment for steel. ${ }^{4}$ As a result, the production of steel increased from 283000 tons in 1914 to 537000 tons in $1918 .^{5}$

Nevertheless, supplies of steel in Japan couldn't keep up with the demand. ${ }^{6}$ Above all, steel imports, which had constituted the majority of steel supplies until then, were disrupted during the war. After Germany and Belgium banned exports to Japan, so did Great Britain and the US in April 1916 and in August 1917 respectively. ${ }^{7}$

In addition, the production capacity of Japanese steel companies was inadequate. For instance, although orders for steel that shipbuilding companies received and accepted during the war amounted to 110000 tons, Yawata Steel Works, which was the biggest steel manufacturer at that time and state owned, was only able to accept orders for 27000 tons in total. ${ }^{8}$ 
According to Seitetsu Sanko Siryo, ${ }^{9}$ from 1914 to 1918, the self-sufficiency ratio of steel for ships was very low. For example, imports of steel for ships during the World War I period comprised more than three-quarters of the demand for steel. In spite of the difficulties regarding imports, most of the steel for ships in this period was imported.

Meanwhile, the steel market continued to be a seller's market. As such, steel customers should have had greater motivation than steel suppliers. Indeed, shipbuilding companies, machine manufacturing companies and metal processing companies demanded even greater amounts of steel from Yawata.

The so-called "iron and steel famine" problem then occurred and steel prices soared. The agreement for the "exchange between Japanese ships and US steel" in 1918 was not able to solve the problem. In particular, because the "exchange" concentrated on steel for big shipbuilding companies, other customers apart from them suffered from the shortage of steel, resulting in small and medium-sized shipbuilding companies, which had recently appeared during the World War I period, taking devastating hits. ${ }^{10}$

\subsubsection{After World War I and the 1920s}

Nonetheless, the market conditions for steel in Japan then changed dramatically when the steel market in Japan became a buyer's market, in contrast to the time during World War I.

Above all, the demand for steel decreased sharply in the first half of the 1920s after World War I. Specifically, since the end of the "shipbuilding boom" was followed by a recession in marine transportation after 1921, the demand for steel for ships decreased sharply. Critically, the conclusion of the Washington Naval Treaty in 1922 strongly influenced naval disarmament, which, in turn, decreased substantially the demand for steel for military use and for warships. ${ }^{11}$

With regard to the supply of steel, the steel factories that had begun to be built towards the end of World War I had not been completed during the war and were then finished one after another after the war ended. Hence, the amount of steel produced expanded rapidly soon after the war. Besides, although two Japanese shipbuilding companies, Kawasaki Shipbuilding Co. and Asano Shipbuilding Co., had started in-house production of steel during the 
war, it was not until 1919 that they were able to produce substantial amounts of steel. ${ }^{12}$

Furthermore, as European countries and the US produced an excess of steel after the war, those countries increased exports to Japan in order to mitigate the problem. In addition, due to the Great Kanto Earthquake of 1923, the speculative import of steel temporarily increased. ${ }^{13}$

\subsubsection{In the 1930s}

In the era of the Great Depression from the end of 1929, the oversupply of steel increased dramatically because of the decline in demand in Japan. The buyer's market continued.

However, along with the recovery from the Depression after about 1932, the demand for steel began to increase. Furthermore, the increase in demand accelerated in the late 1930s. Eventually, steel began to be in short supply, which then became more serious, resulting in another "iron and steel famine", as in World War I. The steel market then became a seller's market again and steel producers had the upper hand over steel customers. In that sense, the steel market in the 1930s shared common characteristics with that of World War I. That is to say, as in the World War I period, there was an excess supply and a seller's market in the 1930s.

On the other hand, compared with World War I, there were significant differences in the period. First, as seen in Table 1.1, in the 1930s Japan had become self-sufficient in steel. In other words, whereas most of the demand for steel was met by imports during World War I, in the 1930s all the demand could be met by domestic production. Moreover, the export rate of domestic steel production was low throughout the 1930s. In a seller's market, Japanese steel producers derived much more benefit due to the expansion in domestic demand.

The high self-sufficiency ratio and the low export rate of domestic steel production meant that the transactions between domestic Japanese steel companies and customers had become more important in the 1930s than in World War I. 
Table 1.1 Domestic steel production, imports and exports (1932-40, thousand tons, \%)

\begin{tabular}{ccccc}
\hline Year & Domestic production & Imports & Exports & Self-sufficiency ratio \\
\hline 1932 & 2123 & 235 & 300 & 103 \\
1933 & 2792 & 410 & 435 & 101 \\
1934 & 3323 & 427 & 596 & 105 \\
1935 & 3978 & 357 & 823 & 113 \\
1936 & 4548 & 345 & 990 & 117 \\
1937 & 5080 & 815 & 773 & 99 \\
1938 & 5489 & 339 & 799 & 109 \\
1939 & 5381 & 197 & 931 & 107 \\
1940 & 5261 & 312 & 793 & 110 \\
\hline
\end{tabular}

Source: Iida et al. (1969, 320); Yonekura $(1994,159)$.

\subsubsection{Steel Transactions in the Prewar Period}

\subsubsection{In World War I}

(1) Big steel producers, small producers and wholesalers During World War I, Yawata increased its sales to the civil market more rapidly than munitions sales; as a result, in 1918, of Yawata's total steel sales, sales to the civil steel market accounted for approximately 40 per cent in terms of quantity and for 60 per cent in value.

In the civil steel market, Yawata mainly limited its steel sales to several big merchants just as before the war. For example, of its total steel sales, Mitsui \& Co. Ltd accounted for 65 per cent and Osaka Kishimoto, Tokyo Morioka and Okuragumi shared the remaining 35 per cent in this period. ${ }^{14}$

Still, there was quite an outcry from steel wholesalers protesting against this sales method of Yawata to limit its trading partners. Therefore, Yawata introduced market factors to its trading. For example, it changed its steel sales method in 1916. Specifically, it adopted a sales method of selling through a bidding process if a certain volume of inventory was accumulated. ${ }^{15}$ The method was to sell to companies wanting to purchase steel, which included customers as well as merchants. In addition, Yawata introduced the 
practice of competitive bidding for steel from the spring of 1918 to November; as a result, the number of companies taking part in the bidding process increased sharply. ${ }^{16}$

Nevertheless, the transactions of steel produced by Yawata were still exclusive, in the sense that the range of Yawata's trading partners was narrow. According to Nagashima (2012), ${ }^{17}$ when Yawata sold its steel by this method, successful bidders were limited to big shipbuilding companies, and steel wholesalers.

In addition, it was not rare for customers to depend largely on specific trading companies in purchasing steel. For instance, at the time when it was extremely difficult to buy steel because of the steel shortage, Kawasaki Shipbuilding Corporation depended heavily on Suzuki \& Co. for purchasing steel. ${ }^{18}$ These facts indicate that the organizational principle worked in steel transactions among Yawata, big customers, and steel wholesalers during World War I.

On the other hand, most new entrants into the steel industry during the war were small companies. ${ }^{19}$ They primarily sold their products to small steel merchants that had had close relationships with them; in other words, the merchants tended to sell the products to small customers. When it was difficult for customers to purchase steel during the steel shortage, small steel producers and steel wholesalers set excess profit margins for steel sales and the transactions were unregulated. In particular, it happened everywhere that merchants suddenly became rich as war profiteers. ${ }^{20}$ In this seller's market, many merchants became rich according to the market principle while those large steel producers limiting their trading partners, as previously noted, represent an organizational principle.

(2) Steel made in Japan and steel imports As described earlier, big steel manufacturers, such as Yawata, controlled steel sales in the World War I period by limiting their trading partners to a few big wholesalers, and big customers. This illustrates the function of the organizational principle in transactions of steel made in Japan.

Simultaneously, the same big wholesalers actively engaged in importing steel. When it became more difficult for Japan to import steel due to the "embargo on imports" of the late stage of World War I, big wholesalers as well as small wholesalers behaved speculatively to gain excess margins. This demonstrates that the market principle functioned, whether it was desirable or not. 
As a result, we can argue that the market principle and the organizational principle were intertwined in the big steel merchants' activities during World War I.

\section{(3) Conflict and cooperation between steel producers and big} customers As mentioned earlier, some shipbuilding companies, such as Kawasaki Shipbuilding and Asano Shipbuilding, began in-house steel production during the war in response to the seller's market for steel. As for the steel producers, this resulted in a decrease in the demand for steel. As a result, by the beginning of in-house steel production by the shipbuilding companies, the interests of shipbuilding companies and steel producers conflicted.

At the same time, Yawata, a main steel producer, supported the in-house steel production of shipbuilding companies. For example, the Fukiai Factory of Kawasaki Shipbuilding dispatched workers to Yawata in order to learn the technology of steel production. Moreover, the factory invited Yawata's engineers to absorb the technology. ${ }^{21}$ Also, to complete the construction of a steel factory, Asano Shipbuilding received technical assistance from Yawata. ${ }^{22}$ This illustrates interfirm cooperation. ${ }^{23}$ In short, cooperation and conflict of interest co-existed between the main steel producers and main steel customers. Similarly, this illustrates the organizational principle and the market principle.

\subsubsection{In the 1920s}

(1) The market and organizational principles in competition Due to the decrease in demand for steel after World War I, Yawata decided to enter the civilian product market. ${ }^{24}$ The serious decline in demand for munitions as a result of the Washington Naval Treaty accelerated the contraction in demand for steel. As a result, Yawata's sales shift to the civilian market was intensified. Accordingly, "the pressure on private steel firms" from government-owned Yawata happened. ${ }^{25}$ Needless to say, private steel companies criticized and condemned such behavior of Yawata.

Furthermore, the pressure on imports increased and intensified competition in the Japanese steel market. Steel imports as a result of the "exchange between Japanese ships and US steel" expanded soon after World War I. As mentioned above, imports from European countries, such as Britain and Germany, increased rapidly. 
German steel firms, in particular, rationalized their facilities and promoted exports to make up what they lost in war reparations. ${ }^{26}$ Besides, the "Customs Tariff Law Amendment" in 1921 increased steel imports, ${ }^{27}$ which continued to increase until the mid-1920s. This indicates that the pressure of competition was strengthened by the increase of imports. Thus, we can observe that this demonstrates the functioning of the market principle.

Yawata intentionally set a price for its steel products slightly lower than the price of the imports in order to compete with European steel companies despite domestic market conditions. ${ }^{28}$ Such a "pricing that imitated import prices" (gaichu kakaku tsuizui) displays the organizational principle as the aim of the pricing was to intentionally stabilize a price change in the end. In short, competition with imports, which represents the market principle, was combined with efforts to stabilize prices, which represents the organizational principle.

Meanwhile, the top five private steel companies established themselves as specialized competitors in some specific market segments along with their growth. Indeed, "the pressure on private steel firms" meant that Yawata extended its range of products so that it came to produce an extremely wide variety of steel products, which raised production costs and resulted in Yawata having higher production costs than the private steel companies. Eventually, the private steel companies succeeded in increasing their market share, while Yawata's market share in most market segments decreased in this period except for the segments in which it had a monopoly. ${ }^{29}$ In the sense that competition between the private companies and Yawata intensified, the market principle in the steel market was strengthened further in this period.

In the late 1920s, several steel cartels were organized in order to alleviate the intense competition among steel companies and to stabilize steel prices. ${ }^{30}$ For example, the Bar Segment Agreement ("Joko Bunya Kyotei"), an agreement regarding product line divisions in steel bars, was established between Yawata and the private steel companies in 1926. Under the agreement, the product lines in steel bars were divided and allocated to Yawata and the private companies respectively by size. The total output of the participants was almost 100 per cent of domestic production. ${ }^{31}$ In addition, in 1927, Nihon Kokan (NKK), Kamaishi and Fuji formed a joint sales 
cartel, the Kanto Steel Material Sales Association ("Kanto Kozai Hanbai Kumiai"), in the field of round bars. The association determined production quotas and sales prices for its members. Indeed, the price of round bars was stabilized by the association ${ }^{32}$ as its participants intended. Such cartels indicate that the principle of organization worked in the Japanese steel market at this time.

At the same time, the members of the Kanto Steel Material Sales Association competed fiercely with each other. For example, despite joining the cartel, the members continued to compete for sales of round bars through their own distribution channels while keeping their close relationship with specific steel wholesalers as they had before the cartel was established. The cartel activity and the close relationship between steel companies and wholesalers illustrate that the organizational principle was intertwined with the behavior of individual companies according to the market principle.

(2) Market and organizational principles in the relationship between steel companies and wholesalers Soon after World War I, many steel wholesalers practiced speculative behavior, such as speculative importing and dumping of sales in response to the sharp change in steel prices. In particular, big wholesalers, more often than not, dealt in imported steel as well as domestic steel products. In fact, the wholesalers that dealt in the steel products of Yawata were importers as well, so they could repeat this speculative behavior in order to gain more profits, comparing the price of Japanese steel with that of imported steel. ${ }^{33}$ Such activities by wholesalers often amplified the fluctuation of market conditions and prices of steel, which clearly reveals the functioning of the market principle.

On the other hand, steel producers tried to control the speculative behavior of big wholesalers. A typical example is the "designated merchants" system that Yawata started in $1925 .{ }^{34}$ In the system, Yawata appointed four big wholesalers as designated merchants: Mitsui \& Co. Ltd Trading Company, Mitsubishi, Iwai \& Company and Ataka \& Company.

In the "designated merchants" system, at first, Yawata determined a price quotation for steel every month by futures contracts. After merchants ordered steel from the designated wholesalers up to each month's deadline, the designated wholesalers collected the orders and negotiated with Yawata. Based on the volume of steel that was 
accepted by Yawata, the designated steel was assigned to the merchants every month.

Under this system, Yawata attempted to control the excessive competition among the designated merchants and to promote cooperation among them. For instance, Yawata helped to establish "the meeting of four companies" (Yonsha-kai) and held a liaison meeting between the four designated merchants.

Moreover, the system also aimed to prevent and exclude the merchants' speculative steel imports. In particular, the designated wholesalers were required to report the prices, the volume and the quality of imports. Yawata determined specific sanctions if they violated the obligation. ${ }^{35}$ In short, in exchange for giving the exclusive rights to sales of Yawata's steel products to the four designated wholesalers, Yawata controlled and limited steel imports under the system.

The system worked well as Yawata intended. Indeed, it contributed to the restraint of imports. Moreover, the system became a stable and convenient method of sales for Yawata. As the "designated merchants" system was so effective, one by one private steel companies introduced the same system as Yawata. ${ }^{36}$ They organized steel sales using the system. As such, the speculative behavior of the wholesalers based on the supply and demand conditions intertwined with the steel makers' action to control the speculative behavior, which represents the organizational principle.

Again, under the system, the organizational principle appeared clearly in the interfirm relationship between the designated wholesalers and other steel merchants. For example, the designated wholesalers received commissions from affiliated merchants while the former financially supported the latter. This behavior demonstrates a kind of principle of organization.

At the same time, the market principle among designated wholesalers was conspicuous. For example, the designated wholesalers competed fiercely with each other to extend their market, using "keiretsu" merchants. ${ }^{37}$ This illustrates the functioning of the market mechanism and the market principle.

Hence, in the "designated merchants" system, the market principle and the organizational principle intertwined complementarily. 
(3) The organizational coping with the downturn in the steel price As described earlier, after World War I, there was excess supply in the Japanese steel market in the 1920s, so that there continued to be a downturn in steel prices. As a result, many steel firms suffered financially. By 1923, only nine iron producers, 22 crude steel producers, and 21 finished steel producers remained in Japan. ${ }^{38}$ As for the detrimental results of management, big steel companies such as Yawata were no exception. The sharp price change, following the fluctuation in demand and supply, resulted in the deterioration in management of the steel companies. From this we can say that the market principle influenced the Japanese steel industry in this period.

The price downtrend and severe management performance caused steel companies to link the production and distribution of steel closely. Indeed, Yawata introduced the "futures contracts" of sales in the late 1920s in order to strengthen the linkage between production and distribution of steel. The representative example is the introduction of the "regular futures contracts". In the contracts, each Yawata factory produced steel only according to the sales plan to be made up based on the future orders from customers.

The introduction of "regular futures contracts" raised the efficiency of production and improved the profitability of the company. First of all, it became easier to make a production plan since each factory could prepare for raw materials and labor in advance to meet the volume of the "futures contract". As a result, unnecessary inventories were reduced and the factories could carry out planned production fully. Second, the factories could gather information about their customers and the market relating to their future production. Third, because they were producing steel in standardized quantity units, problems resulting from the production of many kinds of product in small quantities were alleviated. For instance, the production size per roll increased and the roll changing time improved as well. Eventually, the production efficiency of steel increased. ${ }^{39}$ Yawata's effort to link production and distribution closely meant that a kind of organizational principle worked in response to the arm's length price downtrend and chronic oversupply. Consequently, the introduction and practice of "futures contracts" by Yawata shows the intertwining of the two principles. 


\subsubsection{In the 1930s}

(1) The market principle and the organizational principle in sales methods and distribution routes As emphasized above, the high self-sufficiency ratio implies that the transactions between domestic Japanese steel companies and customers became more important, while excluding steel imports. In addition, because of the short supply of steel in striking contrast to the oversupply during the 1920 s, the Japanese steel market changed drastically into a seller's market, in particular in the late 1930s.

Under such market conditions, Nippon Steel Corporation ${ }^{40}$ (hereinafter referred to as Nippon Steel) employed three sales methods for selling steel: the regular futures contract that was described earlier, the futures contract, and spot trades. All of the three methods were clearly driven by market forces. Therefore, they worked based on the market principle.

However, with regard to the distribution channel of big steel companies, the organizational principle was dominant. For example, in 1936 and 1937 Nippon Steel was selling most steel through three distribution channels: direct sales to customers, the sales through designated wholesalers and the sales to merchants via designated wholesalers. ${ }^{41}$ All of the channels had the characteristics of organizational transactions. As a result, the steel distribution channel in this period mainly exhibits the organizational principle.

(2) Cartel activity and its limitations During the Depression in 1930 and 1931, cartels by producers were established one after another in many kinds of steel market segment except for a few monopoly segments. For example, from 1930 to 1931, cooperative sales associations were organized for black plates, wire rods, plates, medium plates, small angles, and medium angles.

Furthermore, in December 1932, the steel industry became subject to the Strategic Industries Control Act that was enacted to strengthen the control of primary industries by the government in 1932. As the law was applied to the steel industry, cartels in this industry were supported by the government. ${ }^{42}$

These cartels did play important roles in reducing steel imports and in establishing a segmented division of labor between Yawata and the private steel companies. One of the reasons why the cartels 
were rather successful lay in the competitive structure of the industry, ${ }^{43}$ which represents the functioning of the organizational principle. In sum, in the case of steel cartels in this period, we can observe the complementary relationship between the organization principle and the market principle.

Nevertheless, in the same cases, there were conflicts between the aim of cartels and interests of individual firms. Specifically, although the cartels aimed to stabilize prices, there was always a strong temptation for the cartel members to violate the cartel price. From time to time, the cartels failed to stabilize prices and outsiders even appeared, especially in a thin steel sheet cartel. ${ }^{44}$ It was reported that "disintegration" in some cartels began to happen in 1934. ${ }^{45}$ Hence, we can remark that there was a substitutive relationship as well as a complementary one, as illustrated above, between the organization principle and the market principle.

\section{(3) Interfirm relationships between steel producers and wholesalers} In the early 1930s there was a Depression, so that demand for steel decreased rapidly. The steel market changed into a buyer's market, which meant that Yawata's ability to control big merchants became relatively weak. Furthermore, Yawata's "designated merchants" system didn't function well. The same situation continued until the establishment of Nippon Steel.

Nonetheless, when Nippon Steel was established, it set about controlling steel merchants more strongly. In May 1934, the Sales Manager of Nippon Steel announced that they would control a commission of designated merchants and speculative competition among them. ${ }^{46}$ Indeed, Nippon Steel strengthened the "designated merchants" system after August 1935. Under the system the company selected and adopted not only designated wholesalers but designated merchants that were smaller and further downstream than the designated merchants. It meant that the control by the big steel company extended significantly. The organizational relationship between steel producers and merchants was enhanced from the mid-1930s. This is a good example of the principle of organization.

At the same time, the market principle worked in the relationship and the behavior of merchants along with the seller's market. For instance, in particular, from the autumn of 1936, the speculative activity of steel merchants was detrimental, so that even the authoritarian intervention of the Sales Department of Nippon Steel 
did not work. ${ }^{47}$ Furthermore, the individual designated merchants competed quite fiercely with each other. For example, each designated merchant competed to buy further amounts of steel from Nippon Steel while giving credits to small wholesalers. Whereas there was severe competition among the steel merchants, the organizational principle worked simultaneously in the relationship between the steel company and the merchants.

\subsubsection{The Case of Steel Transactions for Ships in the 1930s}

In this subsection, as a case study on the intertwining of the market and the organizational principles, I analyze the steel transactions for ships between Japanese steel companies and shipbuilding companies in the 1930s.

After the mid-1910s, the shipbuilding industry consumed vast amounts of steel. Although the consumption of steel for ships in the early 1910s was only 3 or 4 percent of the total demand for steel, ${ }^{48}$ it increased dramatically during World War I, owing to the "shipbuilding boom". In particular, in 1918, near the end of World War I, the consumption of steel for ships comprised approximately 30 percent of all the domestic steel demand. ${ }^{49}$ Moreover, according to a government report, shipbuilding works consumed over 50 per cent of steel from all machine factories that employed more than 30 laborers in $1918 .^{50}$

While the demand for steel for the use of ships decreased substantially during the 1920 s as a result of the Washington Treaty and following the Depression, the demand for steel for the use of machines, such as ships and electric equipment, was increasing quite rapidly after the recovery from the Great Depression. ${ }^{51}$

Specifically, business in the shipbuilding industry was booming. The value of production in the shipbuilding industry increased from 38 million Yen in 1931 to 111 million Yen in $1936 .{ }^{52}$ Not only warship construction but also the building of private merchant ships increased sharply. Freighters occupied about two-thirds of private merchant ships in the same period. ${ }^{53}$ As a result, through the 1930 s, the shipbuilding industry's demand for steel grew very rapidly in Japan.

Moreover, in contrast to World War I, when Japan largely depended on imports for steel for ships, in the 1930s Japan achieved complete self-sufficiency in thick steel sheet that was 
mainly used for building ships. ${ }^{54}$ This suggests that transactions between Japanese companies became important in the market segment of the 1930s.

The market for steel for ships in this period had the characteristics of the organizational principle. First of all, since the Japanese government tried to promote the marine and shipbuilding industries, the government actively intervened in the transactions of steel for ships. In addition, as with other kinds of steel products, a cartel was established in this market segment. Because they were bilateral oligopolies (both the market for shipbuilding and the market for steel for ships were oligopolistic, as mentioned later), it was highly likely that organizational transactions such as obligational contractual relationships were practiced extensively in this steel market segment. These characteristics were very similar to the so-called "Japanese-style" interfirm relationships after World War I, which many previous studies emphasized.

At the same time, in the seller's market that was a result of explosive increases in demand, the interests of the steel suppliers and steel demanders frequently conflicted and they were even at each other's throats as well as being cooperative. Moreover, they competed fiercely to expand their market shares. Accordingly, it is highly probable that the steel market segment also had the characteristics of the market principle, as well as exhibiting the intertwining of the market principle and the organizational principle. These are the reasons why I examine the transactions of steel for ships in the 1930s.

\subsubsection{Interfirm relationships between cartels}

(1) The organizational principle in transactions between cartels In the early 1930s, both Japanese shipbuilding companies and thick steel sheet producers formed cartels respectively. The shipbuilding companies organized the "Japanese Shipbuilders' Association" (Zosen Rengokai) as a cartel in January 1932. The association consisted of ten shipbuilding companies with the aim of jointly purchasing materials for ships such as thick steel sheet, and building the standard form of shipbuilding contract. In addition, the association assigned steel among its member companies. ${ }^{55}$

In February 1931, the producers of thick steel sheet (more than $6 \mathrm{~mm}$ ) formed a cartel, which consisted of Yawata Steel Works, 
Kawasaki Shipbuilding Corporation, Asano Shipbuilding Corporation and Tokai Kogyo. Indeed, the main members of the cartel were the first three companies, because Tokai Kogyo was virtually a subcontracting company of Yawata Steel Works.

Both cartels carried out substantial transactions for steel for ships in the 1930s. A representative example is the steel transactions for the "subsidy for ship improvement". The "subsidy for ship improvement", which was carried out three times from October 1932 to 1937, was the government policy to promote the breaking up of old ships and, on the other hand, to promote the building of excellent ships. ${ }^{56}$ In this policy, both cartels repeatedly negotiated with each other for steel transactions, which was accompanied by the intervention of the government. For example, In November 1932, the Japanese Shipbuilders' Association held a meeting of the board of directors in order to take measures against soaring steel prices. Based on the conclusion of the meeting, the cartel of shipbuilders continued to negotiate with the thick steel sheet cartel. As a result, agreements on price and quantity were made several times between both cartels. ${ }^{57}$ This implies that a kind of organizational principle worked in this transaction.

With regard to steel prices, in the 1930s they had risen sharply in a seller's market. However, the price of thick steel sheets subsidies for ship improvement was very stable. Specifically, the agreement price of the steel for "subsidy" ships between cartels was kept relatively low compared to the market price (see Table 1.2) ${ }^{58}$ This means that the price was stabilized by the agreement between the cartels. Indeed, both cartels handled steel for "subsidy" ships as "special things". Furthermore, not limited to the transactions of steel for "subsidy" ships, in the late 1930s when steel prices rose sharply, the prices agreed by the cartels considerably stabilized. ${ }^{59}$ This illustrates that the organizational principle worked in the formation of steel prices.

At the same time, it was clear that in the 1930s the Japanese government was attempting to promote the marine and shipbuilding industries and it intervened in order to moderate the skyrocketing of steel prices due to the short supply of steel for ships. As such, the intervention of the government as well as the negotiation between the cartels influenced the formation of prices of steel for ships. For example, the "subsidy for ship improvement" was a government policy, as described above. This policy influenced the negotiation of 


\section{Table 1.2 The price of thick steel sheet (Yen per ton)}

\begin{tabular}{lccc}
\hline Period & $\begin{array}{c}\text { The price of thick } \\
\text { steel sheet for ship } \\
\text { improvement }\end{array}$ & $\begin{array}{c}\text { The price } \\
\text { of thick } \\
\text { steel } \\
\text { sheet }\end{array}$ & $\begin{array}{c}\text { Price quotation of } \\
\text { cartel of thick } \\
\text { steel sheet }\end{array}$ \\
\hline $\begin{array}{l}\text { The second half of } \\
1933\end{array}$ & 130 & 131 & 122 \\
The first half of 1934 & 120 & 136 & 124 \\
$\begin{array}{l}\text { The second half of } \\
1934\end{array}$ & 116 & 153 & 125 \\
The first half of 1935 & 121 & 112 & 108 \\
1936 & 120 & 116 & 106 \\
\hline
\end{tabular}

Source: Senpaku Kaizen Kyokai (1943, 218-33); Hashimoto (2004, 213); Nippon Steel Corporation (1955b).

steel prices between the cartels. Also, as the interests of each ministry conflicted from time to time, adjustment and negotiation among the government ministries was practiced to determine the agreement prices of steel for ships. This suggests that the organizational principle worked, while taking various forms.

(2) The market principle in transactions between cartels At the same time, the market principle worked in the transactions of steel for ships between cartels as well. For example, in the late 1930s, the shortage of supply became more serious so that the supply was insufficient even to satisfy the demand for steel for "ship improvement". In addition, according to a newspaper, when the shipbuilders' association negotiated with the thick steel sheet cartel for a contract for steel for new ships in March 1936, the former requested the deferment of price quotes for the steel to the latter. However, the negotiation ran into difficulties. ${ }^{60}$

These facts suggest that even cooperation between the cartels could not solve the problem of short supply of steel. In other words, the organizational principle was not fully working; hence, the market principle coexisted with the organizational principle in this case.

As a matter of fact, the price level that the shipbuilding cartel requested of the steel cartel sometimes differed considerably from 
the price that the steel cartel wanted to accept. For instance, at the end of 1932, the shipbuilders' association requested steel prices at 96-97 Yen per ton, but the thick steel sheet cartel insisted on 103 Yen per ton for the same steel. ${ }^{61}$

Moreover, conflicts between the cartels over steel prices occasionally took place. For example, although the agreement price for steel between the cartels should have been decided by the end of 1936, it had not even been determined by February 1937. In March 1937 the thick steel sheet cartel requested a new price quote that was 50 Yen per ton higher than the old price quote. The shipbuilders thought that their business might be unprofitable at the new price quoted and that their operation could get into trouble. Therefore, the representative of the shipbuilders' association visited Nippon Steel and petitioned to lower the price quote. ${ }^{62}$ This conflict of interests between both the cartels demonstrates that the market principle as well as the organizational principle was working strongly.

In addition, a severe conflict of interest among member companies of the shipbuilding cartel, Zosen Rengokai, frequently occurred. For example, early in 1933, before the negotiation with the steel cartel regarding steel purchasing, there was an internal complication in the shipbuilding cartel owing to the variance in price that member companies hoped to buy at. As a result, some shipbuilding companies individually engaged in buying steel because it became almost impossible for them to agree on the specific price amongst themselves. ${ }^{63}$ In 1937, during the steel shortage, members of Zosen Rengokai fiercely scrambled to purchase steel for ships, so the government recommended the joint purchase of steel. ${ }^{64}$

Furthermore, those conflicts of interest between cartels and within the cartels also indicate that transactions for steel for ships might have been carried out frequently among individual suppliers and customers, as we will argue later.

\subsubsection{Steel transactions among individual companies}

(1) Reasons It is very likely that suppliers and demanders of steel for ships had reasons why they transacted individually as well as through negotiating between the cartels that they belonged to in this period. 
With respect to the market conditions, as the market for steel for ships in the 1930s was a seller's market, steel producers should have been able to sell on favorable terms at this time. Nonetheless, as described above, the agreement price between the cartels was controlled by the government and the negotiation between the cartels to prevent it from rising sharply. However, steel producers never had a strong motive to keep the price low, although the same agreement price was advantageous to customers. ${ }^{65}$

In addition, in establishing the thick steel sheet cartel, the purpose of the cartel was to stop a sharp fall in the steel price during the Great Depression. Nevertheless, as the economy recovered and a boom came to the steel market, the chief purpose of the cartel changed to controlling the rapid rise of the steel price. Therefore, as for steel companies, the motivation for continuing to be a member of the thick steel sheet cartel was decreasing.

Furthermore, the steel for warships occupied a considerably high proportion of the thick steel sheet market. For example, on average from 1933 to 1935, military demand comprised about 40 per cent of shipments of Yawata and Nippon Steel. ${ }^{66}$ In the late 1930s, Nippon Steel's business relating to military demand was unprofitable. In particular, despite the "steel famine", the severe short supply of steel, Nippon Steel's profit per ton of thick steel sheet decreased after the latter half of $1937 .{ }^{67}$ This highlights that thick steel sheet producers such as Nippon Steel had strong motives to sell the steel for merchant ships, including a motive to transact with individual shipbuilding companies as the transaction was not controlled by negotiation between the cartels.

Moreover, shipbuilding companies also have strong motives to transact with the individual steel producers. Above all, the demand for steel for ships increased so rapidly that the quantity of thick steel sheet to be transacted between cartels was not sufficient to meet the growing demand.

As for the shipbuilding companies, the warship construction business was not profitable in this period. ${ }^{68}$ For example, because Mitsubishi Shipbuilding Co. accepted the order for warships based on the low steel price in 1931 and 1932, it eventually suffered losses due to the rapid rising price of steel. ${ }^{69}$ The skyrocketing steel prices also made the business more unprofitable. As a result, most shipbuilders tried to actively expand the business of merchant shipbuilding in order to increase the purchasing of steel for ships. 
According to the data in Hanbai Jumpo, in the mid-1930s the number of applications for steel by merchants to the thick steel sheet cartel continued to be greater than those that were accepted by the cartel. This implies that the cartel controlled the supply of thick steel sheet in a seller's market and, in turn, the thick steel sheet market was suffering a serious supply shortage.

Moreover, the military demand had had top priority in the allocation of steel so that the shortage of steel for merchant ships became more serious. ${ }^{70}$ Delivery of steel to shipbuilders for merchant vessels was frequently delayed. In response to the problem, as soon as the top shipbuilding companies accepted an order for merchant ships, they made contracts to purchase the steel in order to prevent a critical loss in shipbuilding business due to the steel supply shortage..$^{71}$

Accordingly, it is very likely that shipbuilding companies tried to purchase steel for merchant ships from individual steel companies. This suggests that there were steel transactions between individual shipbuilding companies and steel companies in this period.

\section{(2) Steel transactions among individual companies Again, in the} steel transactions among individual companies, both the market principle and the organizational principle worked simultaneously.

Above all, a continuous and obligational contractual relationship among a few specific companies illustrates the principle of organization. Although it is very difficult to prove the existence of transactions, we can guess that it is highly possible that a continuous and obligational contractual relationship existed in the thick steel sheet market.

The clue is the industrial organization. Namely, both the suppliers' and customers' industry had an oligopolistic structure. Needless to say, industrial organization in both the supply and demand industry is just one factor that determines the type of transaction. However, it is undeniable that the industrial organization greatly affects the type of transaction. Thus, I examine the industrial organization of the shipbuilding industry and the thick steel sheet industry.

Although there were plenty of small companies in the Japanese shipbuilding industry, the production tended to be concentrated in a few large companies. This tendency became more marked as the economy recovered from the Great Depression. For example, in the 
1930s, the top six companies in the Japanese shipbuilding industry constituted more than 90 percent of the shipbuilding market. In particular, the top three companies constituted more than 70 per cent and had a decisive lead over other shipbuilding companies. ${ }^{72}$ In brief, the Japanese shipbuilding industry was an oligopoly.

In addition, the thick steel sheet industry was an oligopoly as well. For instance, Yawata, Kawasaki and Asano had most of the market share during the 1930s along with the sharp increase in production of thick steel sheet. In particular, since its establishment in 1934 Nippon Steel had maintained the top share in the market while the market share of Kawasaki and Asano had fallen since then. ${ }^{73}$

Only a few transaction parties participated in the transaction of thick steel sheet, which implies that obligational contractual transactions of steel, a kind of organizational transaction, were frequently practiced.

Indeed, according to the calculation based on the annual report of the Osaka Iron Works, whose total revenues comprised a high proportion of merchant shipbuilding, it was not until 1936 that its inventory increased rapidly. Considering that the greatest part of the inventory would be made up of steel, it didn't increase its steel stocks very much until 1935 although it could have increased them as much as possible in response to the steel shortage. As such, it is highly probable that it could have bought a stable volume of steel from specific steel companies as a result of an obligational contractual relationship before 1935. This implies the working of the principle of organization in the transaction of steel for merchant ships.

At the same time, the market principle also worked in transactions between individual companies. First, a conflict of interest regarding the transaction volume between steel companies and shipbuilding companies happened frequently. For example, according to a diary of Hirao Hachisaburo, the President of Kawasaki Shipbuilding in 1934, he heard from a bureaucrat when he visited the Bureau of Mines at the Ministry of Commerce and Industry that Zosen Rengokai complained that steel producers did not supply sufficient steel for ships to meet demand. Besides, he added in the same diary that shipbuilding companies suspected and complained that the steel factory of Kawasaki Shipbuilding was shifting some 
of its production capacity of steel for ships to production of other products that were more profitable. ${ }^{74}$

Second, the steel merchants were not good at adjusting the transaction volume of steel between the thick steel cartel and individual shipbuilders, especially at adjusting the quantity of steel supply in relation to demand. For example, according to Hanbai Jumpo, each merchant's share of total volume of applications to the cartel had been fluctuating wildly since the latter half of 1933 .

Third, due to the seller's market in steel, shipbuilding companies fiercely competed with each other for the purchase of steel for ships along with the intense competition in the shipbuilding market. For example, in the "subsidy for ship improvement" that was mentioned earlier, shipbuilding companies competed for application of the policy. ${ }^{75}$

Finally, the thick steel sheet cartel occasionally made spot transactions with individual shipbuilding companies, which primarily represents the functioning of the market principle.

\subsection{STEEL TRANSACTIONS IN THE HIGH ECONOMIC GROWTH PERIOD}

Next, let us move on to a discussion about the steel market in postwar Japan. The purpose of this section is to examine how the market and the organizational principles intertwined in steel transactions in the era of Japan's high-speed economic growth, from around 1955 to 1970 .

As in the 1930s, in this period Japan achieved self-sufficiency in steel. In addition, the ratio of exports to domestic steel production was very low in this period, as in the prewar period. For instance, domestic demand comprised approximately 80 percent of the total demand for Japanese steel products at this time. ${ }^{76}$

In particular, this section focuses on the market segment of steel for ships and automobiles. The reasons are as follows: the demand for steel for shipbuilding had made up a large portion of the demand structure throughout the 1950s and the 1960s, along with demand for machinery and construction. ${ }^{77}$

Similarly, the market segment of steel for automobiles increased very rapidly, and as a result, came to occupy a high percentage of the domestic demand. For example, this market segment was the 
biggest among manufacturing industries purchasing steel by the early 1970s. In addition, the automobile industry demanded very high quality steel products. Thus, the market segment was also important in the sense that it raised the quality level of Japan's steel products.

\subsubsection{Entwining Obligational Contractual Transactions with a Multi-sourcing Policy}

\subsubsection{The market segment for steel for ships}

In the market for steel for shipbuilding, Japanese steel companies carried out obligational contractual transactions with some specific customers.

The shipbuilding industry was an important steel-using industry not only in the prewar period but also in the high economic growth postwar period, as mentioned earlier. In this industry, Mitsubishi Zosen was a leader in the Japanese high growth era. After some M\&As and a change in the company's name to Mitsubishi Heavy Industries $\mathrm{Ltd}^{78}$ in the early $1960 \mathrm{~s}$, the company competed with Hitachi Zosen and Ishikawajima Harima Heavy Industries Ltd for dominance in the industry from 1964 to 1970. Mitsui Zosen and Kawasaki Heavy Industries Ltd followed the top three companies. ${ }^{79}$ The oligopolistic structure of the industry was the same as in the prewar period.

From a previous study, ${ }^{80}$ we have been able to acquire data on steel purchasing quantities by shipbuilding companies in the early 1960s, while preserving the anonymity of the companies. According to Table 1.3, which shows the results of calculations from the study's data, large shipbuilding companies purchased steel, for the most part, from a few steel companies. For example, shipbuilding companies I, J, K, M and $\mathrm{P}$ were purchasing more than 90 percent of steel respectively from only two steel companies in 1961 and 1963. Companies L and Q also purchased more than 80 percent from two steel companies. Hence, the primary Japanese shipbuilding companies purchased steel exclusively from a small number of specific suppliers.

At the same time, the primary steel companies sold steel to only a few shipbuilding companies. According to Table 1.4, steel companies $\mathrm{A}, \mathrm{B}$ and $\mathrm{F}$ sold over 10 percent of their steel to only two shipbuilding companies and $\mathrm{E}$ and $\mathrm{G}$ sold only to three shipbuilding 
Table 1.3 Shipbuilding companies'steel purchasing in 1961 and $1963(\%)$

\begin{tabular}{|c|c|c|c|c|c|c|c|c|}
\hline & & \multirow[b]{2}{*}{ Year } & \multicolumn{4}{|c|}{ Steel Company } & \multirow[b]{2}{*}{ Others } & \multirow[b]{2}{*}{ Total } \\
\hline & & & A & B & $\mathrm{C}$ & $\mathrm{D}$ & & \\
\hline \multirow{18}{*}{$\begin{array}{l}\text { Shipbuilding } \\
\text { Company }\end{array}$} & \multirow[t]{2}{*}{ I } & 1961 & 74 & 18.5 & 0 & 0 & 7.5 & 100 \\
\hline & & 1963 & 71.1 & 12.2 & 0 & 5.4 & 11.3 & 100 \\
\hline & \multirow[t]{2}{*}{$\mathrm{J}$} & 1961 & 5.3 & 27.2 & 0 & 65.4 & 2.1 & 100 \\
\hline & & 1963 & 4.5 & 44.1 & 1.5 & 48.9 & 1 & 100 \\
\hline & \multirow[t]{2}{*}{ K } & 1961 & 0 & 0 & 69.9 & 29.1 & 1 & 100 \\
\hline & & 1963 & 5.5 & 0 & 92 & 0.3 & 2.2 & 100 \\
\hline & \multirow[t]{2}{*}{$\mathrm{L}$} & 1961 & 13.3 & 54.5 & 11.3 & 10 & 10.9 & 100 \\
\hline & & 1963 & 15 & 36.6 & 14.5 & 27.3 & 6.6 & 100 \\
\hline & \multirow[t]{2}{*}{ M } & 1961 & 19.8 & 4.8 & 73.8 & 0.8 & 0.8 & 100 \\
\hline & & 1963 & 8.5 & 0 & 86.6 & 0 & 4.9 & 100 \\
\hline & \multirow[t]{2}{*}{$\mathrm{N}$} & 1961 & 65 & 5.2 & 0 & 23.6 & 6.2 & 100 \\
\hline & & 1963 & 55.4 & 7 & 0 & 28.5 & 9.1 & 100 \\
\hline & \multirow[t]{2}{*}{$\mathrm{O}$} & 1961 & 33.2 & 24 & 5.7 & 27.2 & 9.9 & 100 \\
\hline & & 1963 & 24.8 & 13.5 & 1.6 & 46.1 & 14 & 100 \\
\hline & \multirow[t]{2}{*}{$\mathrm{P}$} & 1961 & 8.4 & 82.4 & 0 & 4.7 & 4.5 & 100 \\
\hline & & 1963 & 0.2 & 81.7 & 1.2 & 2.5 & 14.4 & 100 \\
\hline & \multirow[t]{2}{*}{ Q } & 1961 & 8.8 & 13.7 & 66.6 & 10.5 & 0.4 & 100 \\
\hline & & 1963 & 0 & 2.1 & 54.7 & 41.4 & 1.8 & 100 \\
\hline
\end{tabular}

Source: Sumiya $(1967,183)$.

companies respectively. Again, companies C and D sold over 10 percent of their steel to four shipbuilding companies. In addition, the primary customers of each steel company were different. For example, with regard to sales of steel for ships, the most important customers of steel companies A, B, C and E were different (see Table 1.4). In other words, the primary customers were divided among the steel companies in the transactions of steel for shipbuilding. This implies that big Japanese steel companies exclusively sold steel to a small number of specific building companies. Consequently, we can conclude that the big steel companies and 
shipbuilding companies mainly transacted by obligational contractual transactions and that, in turn, the organizational principle worked in the period.

One of the reasons why these types of transaction were practiced in this period was that the markets of both suppliers and demanders were similarly oligopolistic, as in the 1930s. Thus the postwar market of steel for ships was characterized by organizational transactions for the same reason as it was before the war.

The other important reason why shipbuilding companies made obligational contractual transactions with specific steel producers was to gain their cooperation and trust. For example, in the 1960s, the Yokohama Factory of Mitsubishi Heavy Industries Ltd decided to make NKK the primary supplier of steel for ships since it trusted that NKK would succeed in achieving and maintaining a stable supply of steel of good quality as well as at low prices and that it would comply strictly with delivery dates. ${ }^{81}$

In the obligational contractual relationship, customers and suppliers frequently exchanged important information with each other and cooperated closely. For instance, Fuji Iron and Steel Co. regularly held monthly meetings with the representatives of the shipbuilding companies, which were their most important customers. Fuji expanded these meetings after 1963 as well. ${ }^{82}$ This cooperation is also seen with the organizational principle in the co-development of custom ICs in the 1970s.

On the other hand, the market principle worked in the transactions of steel. According to Table 1.3, the big shipbuilding companies in Japan purchased steel from more than and equal to two companies. In other words, they carried out a "multi-sourcing policy" in purchasing steel products so that they could utilize competition among the companies supplying steel for ships. Another example demonstrates that the market principle functioned in this market. For example, Mitsubishi Zosen and Yawata Iron and Steel Co. made a contract to continue to transact 98000 tons of thick steel sheet for export ships from September 1956 to May 1959. ${ }^{83}$ Yet, owing to the fluctuation of the economy, they failed to renew the arm's length contract thereafter. The organizational principle also entwined with the market principle in the transaction of steel for ships. 
Table 1.4 Steel companies' thick steel sheet sales in the fourth quarter of $1963(\%)$

\begin{tabular}{|c|c|c|c|c|c|c|c|c|c|}
\hline & & \multicolumn{8}{|c|}{ Steel Company } \\
\hline & & A & $\mathrm{B}$ & $\mathrm{C}$ & $\mathrm{D}$ & E & $\mathrm{F}$ & G & $\mathrm{H}$ \\
\hline \multicolumn{10}{|c|}{ Shipbuilding } \\
\hline \multirow[t]{9}{*}{ Company } & I & 35.9 & 9.6 & 0.0 & 2.5 & 9.2 & 16.8 & 21.0 & 4.9 \\
\hline & $\mathrm{J}$ & 1.0 & 8.0 & 0.2 & 17.2 & 3.5 & 0.0 & 0.0 & 1.2 \\
\hline & K & 0.3 & 0.0 & 26.5 & 3.2 & 3.7 & 0.0 & 0.0 & 0.0 \\
\hline & $\mathrm{L}$ & 7.6 & 32.0 & 12.8 & 21.2 & 16.1 & 0.0 & 21.5 & 6.6 \\
\hline & M & 2.7 & 0.5 & 30.6 & 0.0 & 3.0 & 1.8 & 0.0 & 7.0 \\
\hline & $\mathrm{N}$ & 20.8 & 2.7 & 0.0 & 15.5 & 0.5 & 5.1 & 16.9 & 1.0 \\
\hline & $\mathrm{O}$ & 6.7 & 5.5 & 1.5 & 15.5 & 23.9 & 5.0 & 6.4 & 0.0 \\
\hline & $\mathrm{P}$ & 1.4 & 26.6 & 0.2 & 1.3 & 15.9 & 10.6 & 1.5 & 0.0 \\
\hline & Q & 0.3 & 0.9 & 12.6 & 5.6 & 2.1 & 0.0 & 0.0 & 6.1 \\
\hline Others & & 23.3 & 14.2 & 15.6 & 18.0 & 22.1 & 60.7 & 32.7 & 73.2 \\
\hline Total & & 100.0 & 100.0 & 100.0 & 100.0 & 100.0 & 100.0 & 100.0 & 100.0 \\
\hline
\end{tabular}

Source: Sumiya $(1967,169,177)$.

\subsubsection{The market segment for steel for automobiles}

In the late 1950s and 1960s, Japanese automobile companies purchased most of their steel products by obligational contractual transactions. According to an interview with the former manager of a steel-trading company, ${ }^{84}$ about 70 percent of Japanese steel products for automobiles were transacted by obligational contractual relationships. Indeed, in Table 1.5, we can clarify that Toyota and Nissan, which were competing for top company in the Japanese automobile industry, purchased steel from just a few specific steel companies in 1962, and they each bought steel from different steel companies. Other Japanese automobile companies, likewise, used a limited number of steel suppliers. Thus, we can say that the organizational principles functioned in the transaction of steel for automobiles in this period in a similar way to the transaction of steel for ships.

On the other hand, most Japanese automobile companies purchased steel from at least two steel companies. In other words, they carried out a "multi-sourcing policy" in purchasing steel products. For example, according to Table 1.5, Toyota purchased steel 
Table 1.5 Transaction of steel for automobiles in 1962

\begin{tabular}{ll}
\hline Auto makers & Steel producers and share \\
\hline Toyota & Yawata (main supplier), Tokai \\
Nissan & Kawasaki (60\%), Fuji (20\%) \\
Toyo Kogyo & Kawasaki (31\%), Fuji (26\%) \\
Isuzu & Fuji, NKK, Yawata \\
Prince & Fuji (55\%), Yawata (10\%), NKK (10\%), Sumitomo (10\%) \\
Hino & NKK (35\%), Sumitomo (15\%), Fuji, Yawata \\
\hline
\end{tabular}

Source: Sumiya $(1967,48)$.

products not only from Yawata Iron and Steel Co., but also from Tokai Steel, ${ }^{85}$ which was essentially a subsidiary company of Fuji Iron and Steel Co., a rival of the Yawata Iron and Steel Co. Thereafter, Toyota purchased steel for automobiles from the Hirobata Factory of the Fuji Iron and Steel Co. and NKK. This highlights the fact that automobile companies frequently made use of the competition among steel companies. In fact, in the late 1960s and early 1970s, Japanese automobile companies closely watched the change in purchasing share of steel companies and adjusted the share of each steel company every month. ${ }^{86}$

In conclusion, in the transaction of steel for automobiles in Japan, the competition among steel companies and the obligational contractual relationship between steel producers and car producers intertwined. The former and the latter represent the organizational principle and the market principle respectively; thus we can infer that both principles intertwined in the transaction of steel for automobile manufacturing.

\subsubsection{The Market and Organizational Principles in Change of Steel Prices}

\subsubsection{The market segment for steel for ships}

The construction of most ships was strongly supported by the government's "Shipbuilding Plan" in the postwar period, especially in the 1950s. The Japanese government executed the "Shipbuilding Plan" from 1947 to 1987 to secure the necessary amount of vessels 
needed for foreign trade, as well as to create a new and stable demand for Japanese ships. In this new system, according to the information provided by Japanese shipbuilding companies, every year the Japanese government formed a specific plan to build ships according to the estimated requirements for the type and number of ships. Based on the plan and the estimation, the government granted the shipbuilding companies low-interest loans through the government-affiliated financial organizations such as the Japanese Development Bank. Accordingly, the Japanese government intervened in the transactions of steel for ships in the "Shipbuilding Plan", especially in negotiations for the price of steel according to the "plan" between shipbuilding companies and thick steel sheet companies. As a result, the agreement prices of steel for the "plan" ships were considerably stable.

Besides, as shown in Table 1.6, the purchase prices for steel for the primary shipbuilding companies were very stable throughout the 1960s in most primary Japanese shipbuilding companies. This price stability was most likely based on the exclusive and continuous and obligational contractual relationships between the steel and shipbuilding companies, as analyzed above. This implies that the organizational principle worked in steel pricing in the period.

In general, in the Japanese steel market of the period, there were three types of prices: the designated price of the big six steel firms, the sales price of the medium- and small-sized firms, and the market price of the black market. ${ }^{87}$ There was a market price in the thick steel sheet market as well. Indeed, the market price of thick steel sheet, which was chiefly used for ships, had changed dramatically in the late 1950s and the $1960 \mathrm{~s},{ }^{88}$ exhibiting a downward trend throughout the $1960 \mathrm{~s} .{ }^{89}$ In other words, the stable price and the unstable price coexisted in the market of steel for ships in this period. The former was strongly influenced by the market principle and the latter was influenced by the organizational principle.

Moreover, the market price was so sensitive to the tone of the market that it often influenced the steel price in the organizational transactions although the steel distributed at the market price was a small percentage of the total amount of steel. Indeed, according to Table 1.6, the steel purchase price for shipbuilding companies slightly decreased even though it was stable. It is clear that this price decrease was affected by the market price. This is an example that the market principle and the organizational principle interacted. 
Table 1.6 Purchasing prices of steel by main shipbuilding companies in the 1960s (Yen per ton)

\begin{tabular}{|c|c|c|c|c|}
\hline Accounting term & $\begin{array}{l}\text { Mitsubishi } \\
\text { Zosen }\end{array}$ & $\begin{array}{l}\text { Mitsui } \\
\text { Zosen }\end{array}$ & $\begin{array}{l}\text { Hitachi } \\
\text { Zosen }\end{array}$ & $\begin{array}{c}\text { Ishikawajima } \\
\text { Harima }\end{array}$ \\
\hline Ended Sept. 1960 & 47000 & 48000 & 47000 & 48000 \\
\hline Ended Dec. 1960 & 48000 & 48000 & 45000 & 48000 \\
\hline Ended March 1961 & 48000 & 48000 & 46000 & 48000 \\
\hline Ended Sept. 1961 & 48000 & 45000 & 46000 & 48000 \\
\hline Ended Dec. 1961 & 48000 & 45000 & 48000 & 48000 \\
\hline Ended March 1962 & 48000 & 45000 & 48000 & 48000 \\
\hline Ended June 1962 & 48000 & 40710 & - & 48000 \\
\hline Ended Sept. 1962 & 46000 & 40710 & 46000 & 46000 \\
\hline Ended Dec. 1962 & 46000 & 38210 & - & 46000 \\
\hline Ended March 1963 & 44000 & 38210 & 44000 & 46000 \\
\hline Ended Sept. 1963 & 46000 & 38500 & 46000 & 46000 \\
\hline Ended Dec. 1963 & 46000 & 38500 & - & 46000 \\
\hline Ended March 1964 & 46000 & 38500 & 46000 & 46000 \\
\hline Ended Sept. 1964 & 46000 & 41000 & 46000 & 46000 \\
\hline Ended Dec. 1964 & 46000 & 38000 & - & 46000 \\
\hline Ended March 1965 & 46000 & 35000 & 46000 & 46000 \\
\hline Ended June 1965 & 43000 & 44000 & 46000 & 46000 \\
\hline Ended Sept. 1965 & 44000 & 45000 & 46000 & 46000 \\
\hline Ended April 1966 & 44000 & 45000 & 46000 & 46000 \\
\hline Ended Sept. 1966 & 44000 & 45000 & 46000 & 46000 \\
\hline Ended April 1967 & 44000 & 46000 & 46000 & 46000 \\
\hline Ended Sept. 1967 & 44000 & 44000 & 46000 & 46000 \\
\hline Ended April 1968 & 44000 & 43000 & 46000 & 46000 \\
\hline Ended Sept. 1968 & 44000 & 43000 & 46000 & 46000 \\
\hline Ended April 1969 & 44000 & 43000 & 46000 & 46000 \\
\hline Ended Sept. 1969 & 44000 & 43000 & 46000 & 46000 \\
\hline Ended April 1970 & 44000 & 46000 & 47500 & 46000 \\
\hline
\end{tabular}

Source: Each company's annual report. 


\subsubsection{The market segment for steel for automobiles}

Responding to the growth of the Japanese automobile industry in the 1960s, Japanese steel companies actively practiced capital investment. Because the investment was often concentrated on a specific period, the capacity of production of steel for automobiles frequently jumped. Such rapid and discontinuous increases in the steel supply tended to destabilize the situation of supply and demand of steel for automobiles, ${ }^{90}$ despite a rapid increase in the demand for steel for automobiles.

As a result, the price of steel for automobile manufacturing was in a downward trend in this period, ${ }^{91}$ as was that of steel for ships.

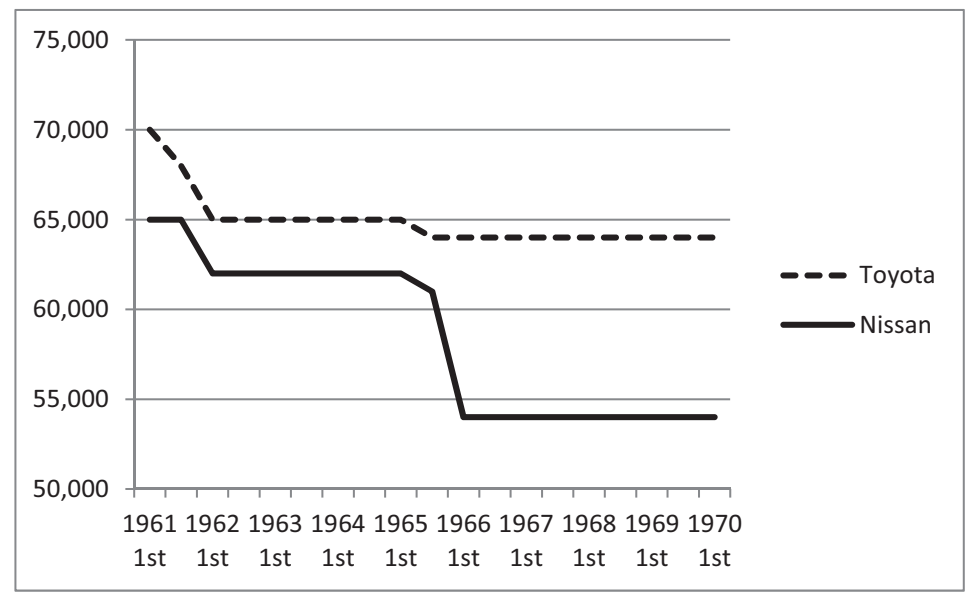

Source: Toyota Jidosha Kogyo, Annual Report; Nissan Jidosha Kogyo, Annual Report.

Figure 1.1 Purchasing steel price for Toyota and Nissan in the 1960s (Yen/ton)

In particular, due to the recession which followed a rapid decrease in demand, the price of steel for automobiles also fell dramatically. For example, the price of cold-rolled steel sheets dropped steeply from October 1963 to October 1964. In the subsequent recessions, some Japanese steel companies sold steel to larger customers at a reduced price and sometimes paid rebates to several important customers. ${ }^{92}$ Accordingly, in the sense that market prices changed 
repeatedly and flexibly depending on the market conditions for steel, the market principle was functioning in the market segment. At the same time, Figure 1.1, which is based on the annual reports of Toyota and Nissan in the 1960s, shows that the purchasing price of steel for Toyota and Nissan in the 1960s was very stable: the price of steel set by the obligational contractual transaction tends to be more stable than the market price. Considering that both the companies predominantly purchased steel by obligational contractual transaction, the consistency of the purchasing prices of steel for automobiles indicates the effectiveness of the organizational principle. Generally speaking, the stability of prices in the transaction demonstrates the effectiveness of the organizational principle. The price of steel for automobiles in the 1960s was no exception.

However, according to interviews, from the late 1950s to the early 1970s negotiations on steel prices between Japanese steel companies and automobile companies were hardly affected at all by the market price, ${ }^{93}$ in contrast with the case of the steel market for ships in the same period. This is an indication of the various ways of interactions between the market price and the arm's length transaction price in different steel market segments.

\subsubsection{Introduction of "Just-in-Time" (JIT) $)^{94}$}

\subsubsection{The market segment for steel for ships}

Through the late 1950s and 1960s, inventory control came to be more significant in this steel market segment. Above all, the demand for steel for ships rapidly increased due to the increase in shipbuilding. Furthermore, because the fluctuation in the demand for ships was enormous, the risk of imbalance between the demand and supply of steel for shipbuilding was high.

Hence, shipbuilding companies made serious efforts to control their steel inventories and by and large this was successful. Table 1.7 highlights data related to the steel inventories of Hitachi Zosen and Mitsui Zosen. According to this table, in these shipbuilding companies, the ratio between term-end inventory and monthly consumption of steel fell throughout the 1960s, whereas the amount of steel consumption continuously increased. 


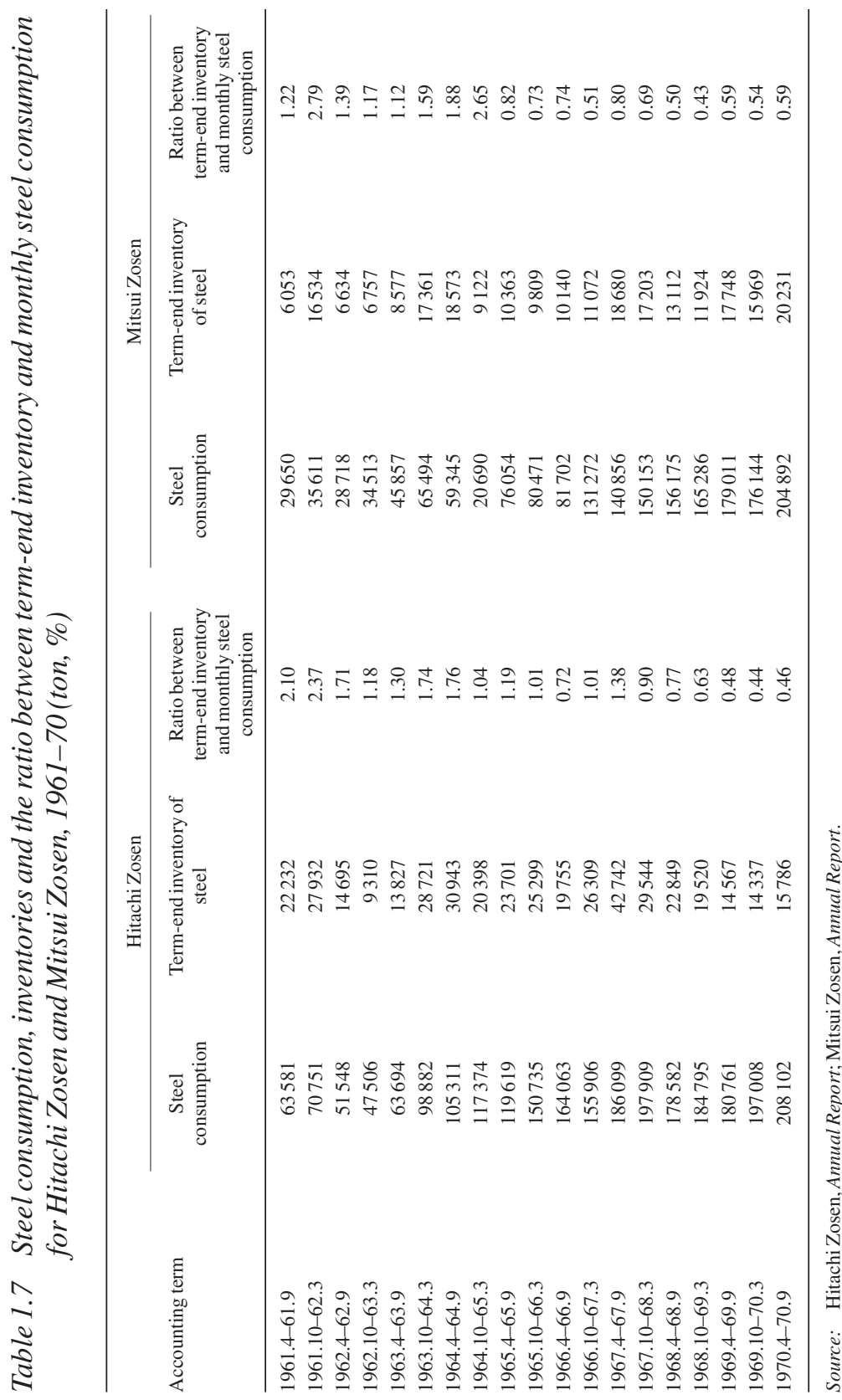


In fact, the "just-in-time" (JIT) system in transactions of steel for ships was introduced in the 1960s. ${ }^{95}$ The incentive to introduce this system was strong in the shipbuilding companies. According to records of Fuji Iron and Steel Co., in the early 1960s Japanese shipbuilding companies firmly requested steel companies to keep strict delivery times and volumes. ${ }^{96}$

Nevertheless, it is obvious that the JIT system raised the costs of delivery and storage for steel companies in transactions with shipbuilding companies. This implies that there was a conflict of interest between steel companies and shipbuilding companies regarding introduction of the system.

Accordingly, cooperation of the steel companies and the shipbuilding companies was critical in introducing and operating the JIT system. Indeed, since the majority of the steel for ships was transacted by obligational contractual relationships, it could have been difficult for steel companies to reject requests from their important customers. In conclusion, cooperation and conflicts intertwined; that is to say, the organizational principle was entwined with the market principle in the introduction of the system.

With regard to the reasons for introduction of the system, it is also important to note that the bargaining power of customers in transactions for steel for ships was increasing in this period.

More specifically, the bargaining power of shipbuilding companies in the second half of the 1960s was stronger than in the first half of the 1960s. For example, although the Customer Sectional Meeting was set up in the Committee for Measures to Market Conditions by MITI and the Japanese steel companies in 1964, the activities of the meeting were limited to supporting research for demand forecasting. This is convincing evidence that steel companies had the initiative in transactions of steel for shipbuilding. ${ }^{97}$ However, in the late 1960s, the bargaining power of shipbuilding companies increased, mainly due to changes in competition in the industries of shipbuilding and steel for ships. Whereas steel for ships became more competitive as a result of the new entry into the market of Sumitomo Steel Co. and steel companies' active capital investment, the shipbuilding industry became more oligopolistic because of M\&As; thus competition in the industry became less intense. Additionally, some building companies changed their systems of materials procurement to strengthen their bargaining power in transactions of materials such as steel. To give a specific 
example, Mitsui Zosen started centralizing its purchasing system by strengthening its "materials purchasing department" at the headquarters of the company in May 1965. The purpose of this change in the organization was to strengthen its bargaining power in purchasing materials - in this case mainly steel - as well as to reduce material costs. ${ }^{98}$ If the bargaining power in the transaction reflected the market principle, this example demonstrates that the organization principle was entwined with the market principle.

Meanwhile, the JIT system in transactions of steel for ships was introduced. In particular, since the price elasticity of the demand for steel for ships was very small and the quality of the steel was standardized, the introduction process of the JIT system worked aptly in this steel segment. As a result, shipbuilding companies could decrease the ratio between term-end inventory and the monthly consumption of steel and, furthermore, they stopped the increase of the inventory in spite of the rapid increase of consumption of steel for ships (see Table 1.7).

\subsubsection{The market segment for steel for automobiles}

In general, changes in steel prices are negatively correlated with changes in the steel inventory. ${ }^{99}$ Thus, the downward trend in the price of steel for automobiles in the 1960s, as we mentioned earlier, reflects the increase in the steel inventory. As such, management of steel stocks became increasingly important for both steel companies and automobile companies. In particular, the consumption of steel for automobiles increased very rapidly as in the case of steel for ships (see Table 1.8), primarily due to the explosive increase in the domestic demand for automobiles of this period: so-called "motorization".

As a result, inventory control of steel for Japanese automobile companies became more important than ever before. ${ }^{100}$ The increase in steel stocks raised automobile companies' inventory costs. The storage space for steel also became far less adequate. In addition, inventory problems brought about problems in product quality and processability: for example, if steel in stock went unused for a considerable period of time, it tended to rust, and its processability decreased. ${ }^{101}$ 
Table 1.8 Steel consumption, inventories and the ratio between term-end inventory and monthly consumption of steel for Toyota, 1960-70 (ton, \%)

\begin{tabular}{|c|c|c|c|}
\hline Accounting term & $\begin{array}{c}\text { Steel } \\
\text { consumption }\end{array}$ & $\begin{array}{l}\text { Term-end } \\
\text { inventory }\end{array}$ & $\begin{array}{c}\text { Ratio between } \\
\text { term-end inventory } \\
\text { and monthly } \\
\text { consumption of steel }\end{array}$ \\
\hline $1960.12-61.5$ & 70022 & 18478 & 1.58 \\
\hline 1961.6-61.11 & 77259 & 15240 & 1.18 \\
\hline $1961.12-62.5$ & 76884 & 13992 & 1.09 \\
\hline $1962.6-62.11$ & 69718 & 10551 & 0.91 \\
\hline $1962.12-63.5$ & 88784 & 9332 & 0.63 \\
\hline 1963.6-63.11 & 89769 & 12520 & 0.84 \\
\hline $1963.12-64.5$ & 93891 & 8148 & 0.52 \\
\hline 1964.6-64.11 & 100798 & 9570 & 0.57 \\
\hline $1964.12-65.5$ & 113710 & 9626 & 0.51 \\
\hline $1965.6-65.11$ & 94204 & 7155 & 0.46 \\
\hline $1965.12-66.5$ & 110885 & 7193 & 0.39 \\
\hline 1966.6-66.11 & 126137 & 7005 & 0.33 \\
\hline $1966.12-67.5$ & 148417 & 7824 & 0.32 \\
\hline 1967.6-67.11 & 166421 & 7479 & 0.27 \\
\hline $1967.12-68.5$ & 184451 & 6480 & 0.21 \\
\hline 1968.6-68.11 & 209655 & 7240 & 0.21 \\
\hline $1968.12-69.5$ & 241158 & 7544 & 0.19 \\
\hline $1969.6-69.11$ & 275197 & 9779 & 0.21 \\
\hline $1969.12-70.5$ & 258672 & 9714 & 0.23 \\
\hline $1970.6-70.11$ & 309414 & 6374 & 0.12 \\
\hline
\end{tabular}

Source: Toyota Motors Co. Annual Report.

Eventually, such inventory problems accelerated the introduction of JIT for steel transactions for automobiles. As a matter of fact, the JIT system was introduced for the transactions of steel with automobile manufacturers in the 1960s. 
Nonetheless, the JIT system raised the delivery and storage costs of Japanese steel companies in transactions with Japanese automobile companies. For instance, under the JIT system, steel companies had to deliver steel more frequently and more quickly in response to the requests from the automobile companies. Steel producers and steel merchants could not expand their storage capacity to match the rapidly increasing demand for steel. This exacerbated the shortage of steel storage capacity. Therefore, steel producers had to deliver steel for automobiles more frequently.

Although the delivery and storage costs increased, the purchasing prices of steel for Japan's big auto producers fell steadily during the period, as previously described. JIT was marked by the conflicts of interest between auto producers and steel producers, as well as the cooperation between them.

Why then did steel companies consent to the introduction of the JIT system in transactions with automobile companies? We do not have critical evidence to provide the answer to this question. However, we can infer that the change of bargaining power in transactions of steel for automobile manufacturing in the 1960s yields clues to help answer this question in the case of automobiles.

Let me illustrate this point in detail using interview records. ${ }^{102}$ According to the interviews, in the transaction of steel for automobiles, Japanese auto producers' bargaining power was far weaker than that of steel companies until the early 1960s. At that time, large Japanese steel producers were superior to the Japanese auto producers with regard to the firms' size, the value of the name, degree of importance in the Japanese economy, the length of history of their businesses, and so on. In fact, the steel companies regarded auto manufacturers as just young mid-sized customers. In negotiations with them, it was the steel companies that determined the final terms of transaction.

Meanwhile, Japanese automobile companies had rapidly strengthened their bargaining power in transactions of steel for automobiles throughout the 1960s. ${ }^{103}$ The reasons for the increase in the auto producers' bargaining power were as follows. First, steel companies' active capital investment in the period resulted in excessive supply in the steel market for automobiles, although the demand for steel increased dramatically. As a result, the oversupply 
favored the auto producers in the steel transactions. Second, Japanese auto producers had grown rapidly in the 1960s, due to the boom in motorization in Japan. Accordingly, the growth rate of Japanese auto producers was higher than that of Japanese steel producers in the period. Finally, because the steel market for automobiles grew more rapidly than other steel market segments, steel companies focused more on the steel market for automobiles. Thus, for steel companies, Japanese auto companies became more important customers. In brief, it is most likely that the change of bargaining power in transactions of steel for automobiles had a major impact on the introduction of JIT.

Additionally, transactions made for many steel products for automobiles were conducted under obligational contractual relationships. Thus, to maintain long-standing business with major clients, steel companies did not reject requests made by top Japanese auto producers even if these requests increased the latter's risk and costs. As a result, the JIT system was introduced in the steel market segment. ${ }^{104}$

As a result of the introduction of JIT in steel procurement, Japanese auto producers resolved the problems in inventory management. For example, the ratio between term-end inventory and Toyota's monthly consumption of steel declined through the 1960 s (see Table 1.8).

Therefore, we can observe that a conflict of interest and cooperation between steel companies and auto producers intertwined in the process of the successful introduction of JIT. Such a conflict of interest between steel companies and automobile companies mainly represented the market principle in the sense that the companies acted according to the price mechanism. On the other hand, cooperation between them represents, for the most part, the organization principle because the companies intentionally tried to limit the price mechanism. Therefore, we can argue that the market principle and the organizational principle intertwined in the process of introduction of JIT.

\subsubsection{Intertwining between Competition and Obligational Contractual Transactions}

The competition among steel companies in the market of steel for ships intensified throughout the late 1950s and 1960s. The change 
in competition, along with the explosion in supply, resulted in the aforementioned change of bargaining power.

When the market for thick steel sheet for ships increased because of the "Production Capacity Expansion Plan" of the Japanese Navy during the Second World War, Nippon Iron and Steel controlled the market. However, in the late 1950s and the first half of the 1960s, Yawata Iron and Steel was joined by Fuji Iron and Steel Co., NKK and Kawasaki Steel Co. in acquiring considerable market shares. ${ }^{105}$ Furthermore, in the late 1960s, Sumitomo Metal Industries Ltd and Kobe Steel Co. also entered this market. In sum, competition in the market for thick steel sheet for ships became more intense. At the same time, along with this intense competition, steel companies attempted to alleviate competition through cooperation such as the "open sales system".

On the other hand, in the market segment of steel for automobiles, since steel companies' active capital investment increased production capacity and resulted in excessive supply in the steel market for automobiles, Japanese steel companies made efforts to expand sales to automobile producers. Moreover, as consumption of steel for automobiles drastically increased due to the auto boom in the 1960s, new entrants appeared in this steel market segment. As a result, competition among steel manufacturers became more intense.

For example, with regard to market share of each company in the market for cold-rolled steel for primary use of automobile manufacturing, just two companies, Yawata and Fuji, were dominant in 1955. However, Kawasaki Steel Co. substantially increased its market share in the late 1950s, while Yawata and Fuji's market shares decreased. Also, in the first half of the 1960s, NKK markedly increased its market share, and Sumitomo Metal Industries Ltd and Kobe Steel Co. entered the market. ${ }^{106}$ The change in market share of each company, in combination with the new entrants to this market, shows that the competition among steel manufacturers became more intense in this market segment.

Under the pressure of competition, Japanese steel companies were forced not only to expand sales to their existing customers, but also to search for new customers. ${ }^{107}$ In particular, they attempted to establish obligational contractual relationships with new customers. 
Let me give some specific examples. When Kawasaki Steel Co. increased its production of strip mill products in its factory at Chiba, the company newly established obligational contractual relationships in the market of cold-rolled steel with one automobile company after another, and kept its policy of prioritizing continuous and obligational contractual transactions. In addition, Kawasaki made new contracts with Suzuki Motor Company and Honda Motor Company in $1964 .{ }^{108}$

When Sumitomo Metal Industries Ltd entered the cold-rolled steel business as a latecomer, ${ }^{109}$ it also focused on the continuous obligational contractual relationship. Since 1961 and throughout the decade, the CEO of the company had focused on the importance of expanding obligational contractual relationships as a marketing policy in a speech at the beginning of every year. The traditional strength of the company had always been in special steel products; from 1961 on, the company made efforts to open up the new product market to specific auto producers, based on their competitiveness.

Furthermore, since Sumitomo's Wakayama Iron and Steel Works began production of cold-rolled sheets in 1963, it continued expanding sales to specific auto producers. In the late 1960s the company began to sell steel to Nissan and Toyota by obligational contractual transactions in 1967 and 1969, respectively. Additionally, it began to sell steel to Mazda Motor Corporation and Mitsubishi Motor Company in 1968 and 1971.

In conclusion, with the rapid increase in the market, intense competition among the steel companies, which represented the market principle, simultaneously expanded the organizational transactions between specific suppliers and customers of steel.

\subsection{THE COMPARISON BETWEEN THE PREWAR PERIOD AND THE HIGH ECONOMIC GROWTH PERIOD}

There is no doubt that there are some differences between interfirm relationships in the Japanese steel industry in the prewar and the high economic growth period, especially differences in the kinds of environment that surrounded these relationships. For example, 
whereas cartels were supported and highly recommended by the Japanese government in the 1930s, they were basically prohibited in postwar Japan. Again, in contrast with the prewar period, there was almost no demand for steel from the Army and Navy after the war, therefore control of demand for steel by the government and Army became lax. In this sense, the principle of organization became weaker in the postwar period than before the war. In contrast, the ratio of steel imports to total demand for steel was very low in the postwar period whereas it had been extremely high during World War I and in the 1920s. In this sense, the market principle became weaker in the postwar period until the 1920s.

Nevertheless, we can observe many similarities between the two periods. The self-sufficiency ratio of steel in the postwar period was as high as in the 1930s. As before the war, the ratio of exports to domestic steel production was very low in the postwar period, especially up to the 1960s. Hence, transactions among domestic companies in the Japanese steel market were very important, not only in the 1930s but in the high economic growth period. Besides, the government intervened in the process of negotiations for the steel price between suppliers and demanders in both periods.

In particular, we can observe that the steel market of the postwar period had a lot in common with that of the prewar period, especially in how the market principle was entwined with the organizational principle. Not only before the war but also after the war, market and organizational principles not only offered alternatives to each other but, depending on the circumstance, also worked in a complementary manner.

First, influenced by the economic fluctuation, seller's and buyer's markets appeared one after the other. While the price of steel rose rapidly in a buoyant market, it decreased in a depressed market. In response to this cyclic change in market conditions and sharp change in the steel price, which represents the market principle, steel companies tried to stabilize the market with some measures such as obligational contractual transactions, cartels and so on, which represented the organizational principle.

Second, in the steel market of both periods, market transactions and the organizational market such as arm's length transactions and transactions between cartels coexisted. These two kinds of transactions influenced each other. For example, the market price and the price of obligational contractual contracts interacted, therefore 
the instability of the market price was entwined with the stability of the price of organizational steel transactions.

Third, both conflicts of interest and cooperation between suppliers and customers appeared. For instance, the process of the introduction of the JIT system in the steel market shows that both conflicts of interest and cooperation between steel suppliers and customers coexisted. Conflicts mostly illustrate the working of the market principle and cooperation primarily demonstrates the working of the organizational principle. These phenomena also occurred in the IC and LCD materials industries, as will be analyzed in Chapter 3 and Chapter 4 respectively. Furthermore, cooperation could be transformed into a conflict of interest, and vice versa, as in the LCD materials industry.

Fourth, there were both competition and cooperation among steel companies and among shipbuilding companies. Moreover, competition and cooperation could appear simultaneously and one could change into the other. If competition and cooperation were closely related to the market principle and the organizational principle respectively, we can argue that in the Japanese steel market, these two principles could coexist and one could be transformed into the other.

Finally, the big steel companies throughout both periods occasionally competed for an expansion of their obligational contractual transactions. For example, they endeavored to increase the number of good customers to make as many obligational contractual transactions as possible, or to increase sales to specific customers. Competition among big steel companies resulted in the expansion of the obligational contractual transaction, a kind of organizational transaction. This phenomenon demonstrates that the market principle could strengthen and support the function of the organizational principle.

\section{NOTES}

1. For example, the representative studies on the Japanese steel and iron industry of the prewar period are Okazaki (1993); Nagura (1984); Nagashima (1987; 2012).

2. Although the dates of the period of high-speed economic growth in postwar Japan have been defined variously by different scholars, in general most 
scholars agree that it was from 1955 to the early 1970s. This book accepts this time frame as being historically valid.

3. Iida et al. (1969, 192); Hashimoto $(1984,39)$.

4. Since the initial investment for these products was relatively low and demand was increasing, many companies entered into production in order to survive (Yonekura, 1994, 90).

5. Iida et al. $(1969,194)$.

6. Iida et al. $(1969,192)$.

7. MITI (1970, 168); Nichibei Sentetsu Kokan Domeshi [The Alliance of Exchange between Japanese Ships and US steel] (1920, 225). In 1917,when the United States, declaring war on Germany, banned steel exports, the Japanese shipbuilders, who had already ordered 450000 tons of steel from the United States, were threatened with being unable to fulfill their contracts (Yonekura, 1994, 79).

8. Zosen Kyokai Kaiho No. 17(37); Shiba (1978, 99).

9. Shokosho Kozankyoku; Nagura $(1984,302)$.

10. Kawasaki Shipbuilding Corporation (1936, 49-50).

11. Nihon Tekkoshi Hensankai (1984b, 30-31, 173); Nagura (1984, 303); Iida et al. (1969, 204, 206); Nagashima (1987, 65). Yawata's third expansion plan was mainly based on the planned fleet expansion of the Navy. The Yawata Works had anticipated 765000 tons in orders from the Navy between 1922 and 1925 , but it received only 60800 tons or 8 percent of what it expected (Yonekura, 1994, 89).

12. Kawasaki Shipbuilding Corporation (1936, 51, 144); Kawasaki Steel Corporation (1976, 262, 269); Kawasaki Heavy Industries Ltd (1959, 81, 91); Nagura (1984, 333, 375); Nihon Tekkoshi Hensankai (1984a, 220, 224, 225).

13. Zenkoku Tekko Tonya Kumiai (1958, 43); Kawasaki Steel Corporation (1976, 262); Nihon Tekkoshi Hensankai (1984a, 82, 158); Nagura (1981, 7, 9).

14. Mitsui \& Co. Ltd (1916 and 1917). Big merchants such as Mitsui \& Co. Ltd, Iwai, Kishiomoto and Shibamoto founded the associations of their affiliated wholesalers respectively (Mishima, 1975, 9). Okura-gumi and Mitsui-gumi were dissolved in 1917.

15. Tetsu to Ko (1916, No. 7, 771 and No. 8, 881); Yamaguchi $(1998,157)$.

16. Hanbai Jumpo (1932, No. 188, 1-2; Nihon Tekkoshi Hensankai (1984a, 101-2); Zenkoku Tekko Tonya Kumiai $(1958,37)$; Nagashima $(2012,653)$.

17. Nagashima (2012, 654-5).

18. Shiraishi (1950, 102); Shiba $(1978,108)$.

19. Nihon Tekkoshi Hensankai (1984a, 165); MITI (1970, 197-8); Iida et al. (1969, 196).

20. Hanbai Jumpo (1932, No. 181); Nihon Tekkoshi Hensankai (1984a, 102); Zenkoku Tekko Tonya Kumiai $(1958,35)$.

21. Kawasaki Steel Corporation $(1976,262)$; Kawasaki Heavy Industries Ltd (1959, 912).

22. Nagura $(1984,375)$.

23. The reason why Yawata behaved like this is not clear. This needs further empirical research.

24. Yonekura $(1994,90)$. In 1919, the Yawata company's sales to the government, including munitions sales, came to 156000 tons, while civilian sales came to 112000 tons. In 1925, sales to the government were 155000 tons. 
25. In order to improve sales to the civil steel market, in 1925 Yawata shifted the Sales Department from Kyushu Prefecture to Tokyo where civil customers for steel were concentrated (Yawata Steel Works, 1950, 59, 228-9); Nippon Steel Corporation (1980, Vol. 1, pp. 505, 510); MITI (1970, 213).

26. Yonekura $(1994,90)$.

27. Kawasaki Steel Corporation $(1976,15)$.

28. On this pricing policy, see Nagashima (2012, 657); Nippon Seitetsu Kabushiki Kaisha Henshu Iinkai (1959); Watanabe (1934); Shiraishi (1933); Tokiwa (1957); Iida et al. (1969); Okazaki (1985; 1993).

29. Okazaki $(1985,108)$.

30. It is evident that the establishment of steel cartels in this period was affected by other factors as many previous studies have pointed out. See the following studies on the steel cartels in this period; Nagashima (1987); Okazaki (1985; 1993).

31. Yawata and the private companies greatly benefited from the agreement. Yawata could reduce the number of its product lines and concentrate on several products. The private firms, on the other hand, could concentrate their production on the most commercially popular medium- and small-sized products without competition from Yawata (Yonekura, 1994, 129-30).

32. MITI $(1970,265)$.

33. Hanbai Jumpo (1932, No. 188, 2 March); Tetsu to Ko (1932, February, 321); Nagashima (2012, 655-6).

34. In the same year, Yawata started the "futures contract" system which was complementary to the "Designated merchants" system.

35. Iida et al. (1969, 268, 293).

36. Nippon Seitetsu Kabushiki Kaisha Henshu Iinkai (1959, 61, 756); Zenkoku Tekko Tonya Kumiai $(1958,61)$.

37. Ataka Sangyo Company (1968, 166-7); Iwai Sangyo Company (1963, 303); Mishima $(1975,10)$.

38. Yonekura $(1994,79,86)$.

39. Shiraishi (1933, 5); Jiji Shimposha (1928, 312-13); Nagashima (2012, 670); MITI (1970, 265).

40. Nippon Steel was established in May 1934 by merging Yawata and some private iron and steel companies.

41. Nihon Tekkoshi Hansankai (1984c, 231-5).

42. Nippon Seitetsu Kabushiki Kaisha Henshu Iinkai (1959, 38).

43. Yonekura (1994, 130-31).

44. Hanbai Jumpo (1933, No. 239); Iida et al. (1969, 295-6).

45. Zenkoku Tekko Tonya Kumiai $(1958,78)$; Iida et al. $(1969,286)$.

46. Nihon Tekkoshi Hensankai (1984c, 189-90).

47. Nihon Tekkoshi Hensankai (1984c, 244).

48. Nagura (1984, 300, 301, 306).

49. Nihon Tekkoshi Hensankai (1984b, 51); Iida et al. $(1969,192)$; Hashimoto (1984, 39).

50. Yoshida $(1928,59-60)$.

51. Shokosho Kozankyoku; Nihon Tekkoshi Hensankai (1984c, 57, 272-3; Hashimoto (2004, 214).

52. Hashimoto $(2004,140)$. 
53. In addition, the ratio of big ships such as ocean liners and tankers increased Osaka Mainichi Shimbun (1937, 5 February); Jiji Shimpo (1936, 24 February); Tokyo Ashahi Shimbun (1936, 8 November).

54. Kozainenppo (1936).

55. Hashimoto (2004, 201-202); Tokyo Ashahi Shimbun (1933, 18 May); Yomiuri Shimbun (1932, 17 November).

56. Kimura (1991, 18); Uraga Senkyo (1957, 269); Chugai Shogyo Shimpo (1937, 31 May).

57. Senpaku Kaizen Kyokai (1943, 218-23); Hashimoto (2004, 212); Tokyo Ashahi Shimbun (1932, 8 November); Yomiuri Shimbun (1932, 25 December); Nikkan Kogyo Shimbun (1933, 22 January).

58. Kimura (1991, 18); Yomiuri Shimbun (1932, 25 December.

59. Yomiuri Shimbun (1937, 4 March, 20 March); Tokyo Ashahi Shimbun (1937, 27 April).

60. Hochi Shimbun (1937, 4 March).

61. Nikkan Kogyo Shimbun (1933, 20 January, 24 January).

62. Yomiuri Shimbun (1937, 4 March); Tokyo Ashahi Shimbun (1937, 4 March).

63. Nikkan Kogyo Shimbun (1933, 5 February, 9 February).

64. Chugai Shogyo Shimpo (1937, 12 February).

65. Hashimoto (2004, 212-3).

66. After the outbreak of the Second Sino-Japanese War, the demand for steel for marine vessels increased rapidly. For instance, Nippon Steel manufactured 71.3 percent and 74 percent of total production of thick steel sheets for military and official requirements in 1939 and 1940 respectively, Nagashima (1983a, 25); Nagashima (1983b, 29, 31). Indeed, most thick steel products manufactured by Yawata were used for marine vessels until the 1920s but it began to commit to steel production for merchant ships in the early 1930 s (Nippon Steel Corporation,1955a, 24).

67. Nagashima (1983b, 27, 29, 44); Nagashima (1981, 540).

68. Hirao Hachisaburo Nikki [The Diary of Hirao Hachisarubo] (1933, 6 October, 21 November, 27 November).

69. Jiji Shimpo (1933, 28 September).

70. Yomiuri Shimbun (1936, 11 December); Nihon Zosen Gakkai (1977, 71).

71. Yomiuri Shimbun (1936, 11 December); Osaka Ashahi Shimbun (1937, 27 January).

72. Hashimoto (2004, 205-7).

73. Shokosho Kozankyoku.

74. Hirao Hachisaburo Nikki (1934, 6 June). According to this diary record, there were conflicts of interest between Kawasaki and integrated steelmakers.

75. Nihon Zosen Gakkai (1977, 312-3).

76. Nihon Tekko Renmei (1969, 203).

77. Iida et al. (1969, 444); Yonekura (1994, 224-5). Demand for steel for construction and engineering in Japan was also very high. However, these market segments were mainly the spot market dominated by the market principle. These segments will not be analyzed in this chapter as I focus on the intertwining between the market and organizational principles in transaction of steel. 
78. In June 1964, Mitsubishi Zosen became Mitsubishi Heavy Industries Ltd by merging with Mitsubishi Nihon Heavy Industries Ltd and Shin Mitsubishi Heavy Industries Ltd.

79. Kumagai $(1973,205)$.

80. Sumiya (1967).

81. Mitsubishi Juko Yokohama Seisakujo (1992, 227).

82. Fuji Seitetsu $(1981,570)$.

83. Mitsubishi Jukogyo (1956, 276).

84. An interview with the former manager of Japanese steel-trading company A (15 December 2005). In 1959, Toyota formalized an arm's length contract with Yawata Iron and Steel Co., which had achieved dominance in Japan's steel industry.

85. Fuji Iron and Steel Co. had the exclusive rights to sales of Tokai Steel Co.'s products after its foundation in 1958, but eventually Fuji merged with Tokai in 1967 (Fuji Seitetsu(1981)).

86. An interview with the former manager in the procurement section of Japanese automobile company B (2008, 10 July).

87. Yonekura $(1994,228)$.

88. See Nihon Tekko Renmei (1969) on the monthly price of thick steel.

89. The most important reason for this downward price trend was the active capital investment by Japanese steel companies during this period. The business of shipbuilding for foreign customers was continually booming, so the demand for steel for shipbuilding continually increased. Furthermore, owing to the general increase in the size of ships, shipbuilding companies began asking steel companies for much wider, heavier and higher-quality steel products. To respond to these requests, steel companies introduced newer and larger equipment. Intense competition in the market for steel for ships accelerated the speed of capital investment by steel companies; as a result, the market was characterized by chronic oversupply. In turn, this excess supply caused steel prices to drop.

In addition, in the first half of the 1960s the price competition among shipbuilding companies for orders by foreign customers gathered intensity. Accordingly, the business of shipbuilding for foreign customers did not pay off, despite the increase in the size of ships (Kumagai, 1973, 228). Thus, shipbuilding companies put pressure on steel companies to reduce their prices.

90. Kim (2011). The large amount of excess supplies sometimes accelerated these exports from the late 1960s. For instance, in 1967, Yawata Iron and Steel Co. exported steel sheets of extra-deep drawing quality to "the Big 3", the three largest American automobile companies, and earned a good reputation for the products (Yawata Seitetsu, 1980, 275-6).

91. The active capital investment contributed to rising productivity with cost reduction, which was a factor in price reduction. For example, the setting up and operation of strip mills greatly increased productivity and quality, and reduced cost in the production of thin steel plates for automobile manufacturing, and rapidly expanded production capacity.

92. Nihon Tekko Renmei $(1969,188)$.

93. An interview with the former manager in the procurement section of Japanese automobile company B (2008, 10 July); Kim (2007). 
94. The "just-in-time" system, which is an essential element of the "Toyota Production System", is a strategy that strives to have the right parts and materials at the right time, at the right place, and in the exact amount.

95. Sumiya (1967, 154-5, 186); the interview in the Nihon Tekko Renmei (2006, 20 December).

96. Fuji Seitetsu (1981).

97. Sumiya $(1967,214-16)$.

98. Mitsui Zosen (1968, 313-4).

99. Ryutsu Sistemu Kaihatsu Senta $(1975,51)$.

100. An interview with the former manager in the procurement section of Japanese automobile company B (2008, 10 July).

101. An interview with the former manager in the procurement section of Japanese automobile company B (2008, 10 July).

102. An interview with the former production manager of Japanese automobile company B (2005, 2 June and 27 June); an interview with the former manager of Japanese steel-trading company A (2005, 15 December); an interview with the former manager in the procurement section of Japanese automobile company B (2008, 10 July).

103. Kim (2011); Kim (2012).

104. Kim (2006).

105. Sumiya $(1967,150)$.

106. Iida et al. $(1969,593)$.

107. Yawata Seitetsu $(1981,542)$.

108. Kawasaki Steel Corporation (1976, 639, 648); Kim (2006, 44).

109. The description in this section is based on Sumitomo Kinzoku Kogyo (1967, 284-5, 294-7, 400) and Sumitomo Kinzoku Kogyo (1977, 106-7).

\section{REFERENCES}

\section{Books}

Ataka Sangyo Company (1968). Ataka Sangyo 60nenshi [The 60-year history of Ataka Sangyo Company], Tokyo.

Fuji Seitetsu [Fuji Iron and Steel Corporation] (1981). Hono to Tomoni: Fuji Seitetsu Kabusiki Gaishashi [With a flame: the history of Fuji Iron and Steel Corporation], Tokyo: Sin Nihon Seitetsu.

Hashimoto, Juro (1984). Taishokoki no Nihon Shihon Shugi [Japanese capitalism in the Great Depression], Tokyo: Tokyo University Press.

Hashimoto, Juro (2004). Senkanki no Sangyo Hatten to Sangyo Soshiki I: Zosen Kogyo [The Japanese industrial development and industrial organization during the interwar period Vol. 1: Shipbuilding industry], Tokyo: Tokyo University Press.

Iida, Kenich, Ohashi, Shuji and Kuroiwa, Toshio (eds) (1969). Gendai Nihon Sangyo Hattatsushi 4 Tekko [Modern Development of Japanese Industries 4: Steel Industry], Tokyo: Kojunsha Shuppankyoku. 
Iwai Sangyo Company (1963). Iwai 100nenshi [The 100-year history of Iwai Sangyo Company].

Jiji Shimposha (ed.) (1928). Nihon Sangyo no Gorika [The rationalization of Japanese industries], Tokyo: Toyo Keizai Inc..

Kawasaki Jukogyo [Kawasaki Heavy Industries Ltd] (1959). Kawasaki Jukogyo Kabushiki Kaishashi [The history of Kawasaki Heavy Industries Ltd], Kobe.

Kawasaki Seitetsu [Kawasaki Steel Corporation] (1976). Kawasaki Seitetsu 25nenshi [The 25-year history of the Kawasaki Steel Corporation], Kobe.

Kawasaki Zosen (1936). Kawasaki Zosenjo 40nenshi [The 40-year history of the Kawasaki Shipbuilding Corporation], Kobe.

Kawasaki Zosen. Annual Report.

Kumagai, Hisao (ed.) (1973). Nihon no Sangyo Soshiki 1 [Industrial organization in Japan 1], Tokyo: Chuo-Koronsha.

MITI (Ministry of International Trade and Industry) (1970). Shoko Seisakushi [The history of policy by the Ministry of Commerce and Industry] Vol. 17: The iron and steel industry, Tokyo.

Mitsubishi Juko Yokohama Seisakujo [Yokohama Factory of Mitsubishi Heavy Industries Ltd] (1992). Mitsubishi Juko Yokohama Seisakujo 100nenshi [The 100-year history of the Yokohama factory of Mitsubishi Heavy Industries Ltd].

Mitsubishi Jukogyo [Mitsubishi Heavy Industries Ltd] (1956). Mitsubishi Jukogyo Kabushiki Gaishashi, Tokyo.

Mitsui Zosen [Mitsui Zosen Corporation] (1968). Mitsui Zosen Kabusiki Gaisha 50 nenshi [The 50-year history of the Mitsui Zosen Corporation], Tokyo.

Nagashima, Osamu (1987). Senzen Nihon Tekkogyo no Kozo Bunseki [The structure analysis of the iron and steel industry in prewar Japan], Kyoto: Minerva Shobo Co. Ltd.

Nagashima, Osamu (2012). Kokuei Yawata Seitetsujoron: Kokka Shihon no Keieishi [The studies on Yawata Steel Works, government enterprise: business history of state capital], Tokyo: Nihon Keizai Hyoronsha Ltd.

Nagura, Bunji (1984). Nihon Tekkogyoshi no Kenkyu: 1910 Nendai kara Sanjunendai Zenhan no Kozoteki Tokucho [The studies on the history of Japanese iron and steel industry: the structural characteristics from the 1910s to the early 1930s], Tokyo: Kondo Shuppansha.

Nichibei Sentetsu Kokan Domeshi [The alliance of exchange between Japanese ships and US steel] (1920).

Nihon Tekko Renmei [The Japan Iron and Steel Federation] (1969).Tekko 10nenshi: Showa 33nen-42nen [The past 10 years of the Japanese iron and steel industry], Tokyo: Nihon Tekko Renmei.

Nihon Tekkoshi Hensankai [The Editing Committee of Japanese Iron and Steel History] (ed.) (1984). Nihon Tekkoshi: Taisho Zenki-hen [Japanese iron and steel history: the early Taisho era], Tokyo: Bunsei Shoin. 
Nihon Tekkoshi Hensankai [The Editing Committee of Japanese Iron and Steel History] (ed.) (1984). Nihon Tekkoshi: Taisho Koki-hen [Japanese iron and steel history: the latter part of Taisho era], Tokyo: Bunsei Shoin.

Nihon Tekkoshi Hensankai [The Editing Committee of Japanese Iron and Steel History] (ed.) (1984). Nihon Tekkoshi: Showa Daiikki-hen [Japanese iron and steel history: the first period of Showa era], Tokyo: Bunsei Shoin.

Nihon Zosen Gakkai [The Society of Naval Architects of Japan] (ed.) (1977). Showa Zosenshi I [The history of shipbuilding industry in Showa period Vol. 1], Tokyo: Hara Shobo.

Nippon Seitetsu Kabushiki Kaisha Henshu Iinkai [The Editing Committee of Nippon Steel Corporation] (ed.) (1959). Nihon Seitetsu Kabushiki Kaishashi [The history of Nippon Steel Corporation], Tokyo.

Nippon Steel Corporation (1955a). Nittetsu Shasi Eigyo-hen: Hanbai Kankei Kaiko Zadankai [The sales history of the Nippon Steel Corporation: recollection discussion meeting], shorthand notes, Tokyo: 15 October.

Nippon Steel Corporation (1955b). Nittetsu Shasi Henshu Siryo [The editing documents of Nippon Steel Corporation] No. 196, Tokyo.

Nippon Steel Corporation (1980). Yawata Seitetsujo 80nenshi:Bumonshi [The 80-year history of the Yawata Steel Works: the history of departments] Vol. 1, Tokyo.

Okazaki, Tetsuji (1993). Kogyoka to Tekkogyo: Keizai Hatten no Hikaku Seido Bunseki [The industrialization and steel industry: comparative institutional analysis of economic development], Tokyo: Tokyo University Press.

Ryutsu Sistemu Kaihatsu Senta [The Distribution Systems Research Institute] (1975). Shohinbetsu Ryutsu Kozo Chosa 'Kozai' Hokokusho (1) [A research report on the distribution system of steel by commodities (1)]. Tokyo.

Senpaku Kaizen Kyokai [Ship Improvement Association] (1943). Shadan Hojin Senpaku Kaizen Kyokai Jigyoshi [The history of activity of the Ship Improvement Association], Tokyo.

Shiraishi, Yuji (ed.) (1950). Kaneko Naokichi Den [A life of Kaneko Naokichi].

Sumitomo Kinzoku Kogyo Kabushiki Gaisha Shashi Hensan Iinkai [The Compilation Committee for History of Sumitomo Metal Industries, Ltd] (1967). Sumitomo Kinzoku Kogyo Saikin 10nenshi [The past 10 years of Sumitomo Metal Industries Ltd], Osaka.

Sumitomo Kinzoku Kogyo Kabushiki Gaisha Shashi Hensan Iinkai [The Compilation Committee for History of Sumitomo Metal Industries, Ltd] (1977). Sumitomo Kinzoku Kogyo Saikin 10nenshi [The past 10 years of Sumitomo Metal Industries, Ltd], Osaka. 
Sumiya, Mikio (ed.) (1967). Tekkogyo no Keizai Riron [Economic theory of the steel industry], Tokyo: Nihon Hyoronsha.

Tokiwa, Kaichiro (1957). Tekko Karuteru Hensenshi [The history of steel cartels], Tokyo: Sogo Keizai Kenkyujo Shuppankyoku.

Uraga Senkyo [Uraga Dock Company] (1957). Uraga Senkyo 60nenshi [The 60-year history of the Uraga Dock Company], Tokyo.

Yamaguchi, Kazuo (1998). Kindai Nihon no Shohin Torihiki: Mitsui Bussan wo Chusin ni [Commodity trading in modern Japan], Tokyo: Toyoshorin.

Yawata Seitetsu [Yawata Iron and Steel Corporation] (1980). Yawata Seitetsujo 80nenshi: Sogoshi [The 80-year history of the Yawata Steel Works: overall history], Tokyo: Sin Nihon Seitetsu.

Yawata Seitetsu [Yawata Iron and Steel Corporation] (1981). Hono to Tomoni: Yawata Seitetsu Kabusiki Gaishashi [With a flame: the history of the Yawata Iron and Steel Corporation], Tokyo: Sin Nihon Seitetsu.

Yawata Steel Works (1950). Yawata Seitetsujo 50nenshi [The 50-year history of the Yawata Steel Works], Yawata.

Yonekura, Seiichiro (1994). The Japanese Iron and Steel Industry, 18501990: Continuity and Discontinuity, New York: St Martin's Press.

Yoshida, Toyohiko (1928). Honpo Seitetsu Kogyo ni taisuru Shirotokan [Outlook on the Japanese Iron and Steel Industry], Tokyo: Kaikosha.

Zenkoku Tekko Tonya Kumiai [Japan Iron \& Steel Wholesalers Association] (1958). Nihon Tekko Hanbaishi [The History of Japanese Steel and Iron Sale], Tokyo.

\section{Articles, Chapters and Essays}

Kim, Yongdo (2006). "Choki Aitai Torihiki to Sijo Torihiki no Kankei ni tsuiteno Kosatsu: Kodo Seichoki Zenhan ni okeru Tekko no Torihiki [Relations between long-term continuous transactions and free market transaction: the case of steel transaction in the era of Japanese highspeed growth]", Keisirin (Department of Business Administration of Hosei University), 42(4).

Kim, Yongdo (2007). "Kodo Seichoki ni okeru Jidoshayo Kozai no Kigyokan Torihiki [Inter-firm relationships in transaction of steel for autos during the era of Japanese high-speed growth]", Innovation Management (Innovation Management Research Center of Hosei University), Vol. 4.

Kim, Yongdo (2011). "Tekkogyo: Setsubi Toshi to Kigyokan Torihiki [The iron and steel industry: capital investment and inter-firm transactions]", in Takeda, Haruhito (ed.), Kodo Seichoki no Nihon Keizai [The Japanese economy in the high growth period], Tokyo: Yuhikaku.

Kim, Yongdo (2012). "The inter-firm relationship and 'just-in-time' in Japan's steel industry, 1955-1970”, Journal of Innovation Management (Hosei University), No. 9. 
Kimura, Takatoshi (1991). "Senzen Nihon Zosengyo Bunseki [The analysis of the pre-war shipbuilding industry]", Keizai Shishu, 60 (4).

Mishima, Yasuo (1975). "Steel cartel and General Trading Companies of prewar Japan: case of Mitsubishi Corporation", Konan Keiei Kenkyu, 16(3).

Nagashima, Osamu (1981). "Nihon ni okeru Senji Tekko Tosei no Seiritu Katei: Seitetsu Jigyoho Seiritsu no Zentei [The establishment of wartime control to the iron and steel industry: the premise of the steel industry law]", Ritsumeikan Keieigaku, 20(3/4).

Nagashima, Osamu (1983a). "Nihon Seitetsu Kabushiki Kaisha no Keiei Kozo I [The business structure in establishment of Nihon Steel Corporation I]", Ritsumeikan Keieigaku, 22(3).

Nagashima, Osamu (1983b). "Nihon Seitetsu Kabushiki Kaisha no Keiei Kozo II [The business structure in establishment of Nihon Steel Corporation II]", Ritsumeikan Keieigaku, 22(4).

Nagura, Bunji (1981). "The history of Japanese steel and iron industry in the interwar period", Rekisigaku Kenkyu, 489.

Okazaki, Testuji (1985). "Kanto Kozai Hanbai Kumiai to Kozai Rengokai [The Kanto Steel Selling Association and the Steel Association]", in Hasimoto, Juro and Takeda Haruhito (eds), Ryo Taisenkanki Nihon no Karuteru [The Japanese cartels in the interwar period], Kyoto: Ochanomizu Shobo.

Shiba, Takao (1978). "Taishoki Kigyo Keiei no Takakuteki Kakudai Siko to sono Zasetsu: Kawasaki Zosenjo no Baai [The growth and failure of Japanese diversified firms in the Taisho era]", Osaka Daigaku Keizaigaku, 28(2/3).

Shiraishi, Motojiro (1933). "Tekko Torihiki" [Steel transaction], Sijo Keizai Koza Dai 2kan [The lecture of market economy]", Vol. 2, Tokyo: Shunjusha.

Watanabe Masando (1934). "Tekko Torihiki no Hatten Katei, Present State, Shorai" [The type, current and future of development of steel transaction]", Keiei Kenkyu, 2(3).

\section{Trade Journals, Newspapers and Data}

\section{Chugai Shogyo Shimpo}

Hitachi Zosen [Hitachi Shipbuilding Corporation]. Annual Report.

Hochi Shimbun.

Ishikawajima Harima[Ishikawajima Harima Heavy Industry Corporation]. Annual Report.

Japan Iron \& Steel Co. Ltd. Kozainenppo [Steel Sheet Annual Report].

Jiji Shimpo.

Mitsubishi Zosen. Annual Report.

Mitsui Zosen. Annual Report.

Nikkan Kogyo Shimbun. 
Nissan Jidosha Kogyo [Nissan Motor Company]. Annual Report.

Osaka Ashahi Shimbun.

Osaka Mainichi Shimbun.

Tetsu to Ko [Iron and Steel].

Tokyo Ashahi Shimbun.

Toyota Jidosha Kogyo [Toyota Motor Corporation]. Annual Report.

Yawata Seitetujo/Nippon Steel Corporation. Hanbai Jumpo.

Yomiuri Shimbun.

Zosen Kyokai [Japanese Shipbuilding Association]. Zosen Kyokai Kaiho [Japanese Shipbuilding Association Bulletin].

\section{Archival Sources}

Hirao Hachisaburo Nikki [The Diary of Hirao Hachisaburo].

Shokosho Kozankyoku [The Mining Bureau of Ministry of Commerce and Industry] ed. Seitetsugyo Sanko Siryo [Reference Materials of Steel and Iron Industry].

Mitsui \& Co. Ltd (1916, 1917). The Minutes of the Fourth Branch Managers' Meeting. Tokyo: Mitsui Bunko.

\section{Interviews}

Interviews with the former production manager of Japanese automobile company B (2 June and 27 June 2005).

Interview with the former manager of Japanese steel-trading company A (15 December 2005).

Interview in the Japan Iron and Steel Federation (20 December 2006).

Interview with the former manager in the procurement section of Japanese automobile company B (10 July 2008). 